\title{
Study of selective deposition mechanism of cerium-based conversion coating on Rheo-HPDC aluminium-silicon alloys
}

\author{
1. Maryam Eslami (Corresponding author) \\ Department of Industrial Engineering, University of Trento, Via Sommarive 9, 38123 Povo (TN), Trento, Italy \\ Email: maryam.eslami@unitn.it, Tel: +39-3899121304, Fax: +39-0461281977 \\ 2. Michele Fedel \\ Department of Industrial Engineering, University of Trento, Via Sommarive 9, 38123 Povo (TN), Trento, Italy \\ Email: michele.fedel@unitn.it \\ 3. Giorgio Speranza \\ Center for Materials and Microsystems, Bruno Kessler Foundation (FBK), Via Sommarive 18, 38123 Povo (TN), \\ Trento, Italy, Email: speranza@fbk.eu \\ 4. Flavio Deflorian \\ Department of Industrial Engineering, University of Trento, Via Sommarive 9, 38123 Povo (TN), Trento, Italy \\ Email: flavio.deflorian@unitn.it \\ 5. Nils-Eric Andersson \\ Department of Materials and Manufacturing, School of Engineering, Jönköping University, Gjuterigatan 5, Box \\ 1026, 55111, Jönköping, Sweden, Email: nils-eric.andersson@ju.se \\ 6. Caterina Zanella \\ Department of Materials and Manufacturing, School of Engineering, Jönköping University, Gjuterigatan 5, Box \\ 1026, 55111, Jönköping, Sweden, Email: caterina.zanella@ju.se
}

\begin{abstract}
Cerium-based conversion coatings were deposited on rheocast $\mathrm{Al}-\mathrm{Si}$ alloys by immersion in cerium nitrate aqueous solutions. Rheocast AlSi alloy have a heterogeneous microstructure and present a challenge for pretreatments. Different parameters were studied to optimize the conversion coating, and $\mathrm{NaCl}$ or $\mathrm{H} 2 \mathrm{O} 2$ were also addied to the treatment to modify or accelerate the deposition process. The mechanism of the coating formation was studied by means of focused ion beam milling (FIB) assisted SEM. the results show that applying cerium-based conversion coating to Al-Si alloys, is possible and a preferential deposition is obtained due to the presence of iron-rich intermetallic particles inside the eutectic region. The formation mechanism of selectively deposited cerium-based conversion coating includes dissolution of aluminium matrix, selective dissolution of aluminium near to the noble intermetallic particles, oxidation of iron from the intermetallic particles, and the deposition of cerium hydroxide/oxide layer. the results reveal that the improvement in corrosion resistance in the presence of selectively deposited ceriumbased conversion coating is more significant compared to the homogenous coating deposited from the conversion solution containing $\mathrm{H}_{2} \mathrm{O}_{2}$.
\end{abstract}

Keywords: Cerium-based conversion coating; Al-Si alloy; Rheo-HPDC; Corrosion 


\section{Introduction}

Conversion coatings are oxide-based coatings which have been utilized to replace the native oxide film on a metal surface such as aluminium, zinc, or magnesium to provide higher corrosion resistance [1]. For many decades, chromium-based conversion coating ( $\mathrm{CrCC}$ ) has been used due to its extensive corrosion protection, especially for aluminum alloys. However, concerns and new restrictions about the environmental hazards of chromium compounds [2] have led to intensive efforts to develop alternative pretreatments [3].

Corrosion inhibitive effect of rare earth metal salts for aluminium alloys was first discovered by Hinton et al. back in the 1980s [4]. These salts were found to be non-toxic, relatively cheap, and abundant [5]. Not only pioneer studies [5], but recent ones [6] have also emphasized that cerium-based salts and subsequently cerium-based conversion coatings are the most effective in the sense of corrosion inhibition over other lanthanide-based conversion coatings. Cerium-based conversion coating $(\mathrm{CeCC})$ was also shown to possess self-healing properties under specific conditions[7], a feature which is the unique for CrCC.

Cerium-based conversion coatings consist of a combination of Ce (III) and Ce (IV) hydroxide/oxide layers [8, 9] formed on the metal surface due to the metal electrochemical activity. Sharing the same common characteristics, cerium-based conversion layers exhibit morphologies and compositions, which are specific to the substrate composition and microstructure [10]. A local $\mathrm{pH}$ increase due to the cathodic activities, such as oxygen or hydrogen peroxide reduction reactions (in $\mathrm{H}_{2} \mathrm{O}_{2}$ containing solutions) can result in cerium hydroxide/oxide precipitation:

$$
\begin{aligned}
& \mathrm{O}_{2}+2 \mathrm{H}_{2} \mathrm{O}+4 \mathrm{e}^{-} \rightarrow 4 \mathrm{OH}^{-} \\
& \mathrm{H}_{2} \mathrm{O}_{2}+2 \mathrm{e}^{-} \rightarrow 2 \mathrm{OH}^{-} \\
& \mathrm{Ce}^{3+}+3 \mathrm{OH}^{-} \rightarrow \mathrm{Ce}(\mathrm{OH})_{3} \\
& 4 \mathrm{Ce}^{3+}+\mathrm{O}_{2}+4 \mathrm{OH}^{-}+2 \mathrm{H}_{2} \mathrm{O} \rightarrow 4 \mathrm{Ce}(\mathrm{OH})_{2}{ }^{2+} \\
& \mathrm{Ce}(\mathrm{OH})_{2}{ }^{2+}+2 \mathrm{OH}^{-} \rightarrow \mathrm{Ce}(\mathrm{OH})_{4} \rightarrow \mathrm{CeO}_{2}+2 \mathrm{H}_{2} \mathrm{O}
\end{aligned}
$$

The cathodic reactions occur over the phases with higher potential with respect to the aluminium matrix, therefore the role of these phases (for instance intermetallic (IM) particles) and their influences on CeCC are worth to be investigated. There are many papers supporting the idea that the deposition of cerium-based compounds starts locally on the cathodic IM particles [11-13] while the lateral growth of the coating and the integration of small precipitations lead to covering the whole surface $[4,8]$.

Researches on the formation mechanism of $\mathrm{CeCC}$ have been mainly focused on alloys for aerospace applications such as AA2024 [8, 9, 11-28] and AA7075 [19, 29-36]. In these alloys the role of copper-rich and other noble IM particles on the deposition of cerium-based layers has been widely studied [11-13, 27, 28]. Most of the IM particles in copper containing alloys are cathodic with respect to the aluminium matrix (such as $\mathrm{AlFeMnCu}$ ). However, anodic particles such as $\mathrm{Al}_{2} \mathrm{CuMg}$ (S-phase) also participate in the deposition mechanism after dealloying (selective dissolution of magnesium and aluminium) making them nobler compared to the aluminium matrix [13, 27]. A further model [27] states that even a small dissolution of magnesium and the consequent hydrogen evolution can locally increase the $\mathrm{pH}$ high enough for cerium hydroxide/oxide precipitation. In this way, precipitation of cerium-based 
compounds on the IM particle can happen even before it becomes cathodic. Other studies [13] showed that copper dissolution from S-phase during the deposition of the conversion coating and the further cathodic reduction of copper ions on the matrix result in the formation of copper islands. This phenomenon promotes more dissolution of surrounding aluminium matrix leading to areas of major oxide growth. Interestingly, the composition of cerium layer differs from $\mathrm{CeO}_{2}$ on more active cathodic IM particles ( $\left.\mathrm{AlCuFeMn}\right)$ to $\mathrm{Ce}\left(\mathrm{O}_{2}\right)(\mathrm{OH})_{2}$ over the aluminium matrix. The oxide layer over S-phase changes from aluminium oxide to an aluminium oxide containing copper oxide and cerium oxide [13].

The study by Hughes et al. [14] on the formation kinetics of cerium hydroxide/oxide layer on AA2024 showed that the coating deposition occurs in two stages involving induction and deposition. Induction step was found to involve the deposition of cerium-based compounds over the cathodic IM particles together with aluminium oxide growth while the deposition step involves deposition of cerium-based compounds over the surface.

Despite many researches on the formation of $\mathrm{CeCC}$ on different aluminium alloys, only a few works $[37,38]$ have been reported on the formation of CeCCs on cast Al-Si alloys.

High Pressure Die Casting is a commonly used casting process for the majority of light alloy components [39, 40]. Recently, this process has been integrated with semi-solid metal processing such as rheo-casting to introduce a new casting technology (called Rheo-HPDC) for producing high-quality components with sound microstructure [40-43]. Rheo-HPDC widens the composition range of castable alloys, but unfortunately, it also increases the inhomogeneity of the microstructure in the final component in comparison to the conventional HPDC process [44]. Previous studies showed that this microstructural inhomogeneity together with the presence of the eutectic silicon phase and iron-rich IM particles can result in pitting corrosion in chloride containing environments which differs in various positions of the component [45]. It can be expected that the complexity of the microstructure in Rheo-HPDC aluminium alloys can influence the formation of CeCCs.

This paper focuses on the formation mechanism and characterization of CeCC on Rheo-HPDC low silicon content aluminium alloys. Focused ion beam milling scanning electron microscope (FIB-SEM) as an adequate tool to study the of the substrate and surface features beneath the CeCC. This method has also been used by other researchers such as Pinc et al. [22] to study the formation of subsurface crevices during the cerium conversion process. Electrochemical impedance spectroscopy (EIS) and potentiodynamic polarization were applied to investigate the electrochemical behavior of CeCCs. Two Al-Si alloys with 2.5 and 4.5 wt.\% silicon were chosen to be treated by the conversion treatment in order to examine the effect of silicon content on the process. The pretreatment optimization was obtained by varying the coating process parameters such as immersion time, concentration of cerium ions, chloride ions, and hydrogen peroxide on the deposition and the corrosion resistance of CeCCs.

\section{Experimental}

\subsection{Rheo-HPDC process}

Components of two Al-Si alloys with the measured compositions of (wt.\%) Si: 2.41, Fe: 0.46, Cu: 0.13, Mn: 0.02, Mg: 0.58, Zn: 0.04, Al: balance (2R) and Si: 4.5, Fe: 0.48, Cu: 0.13, Mn: 0.02, Mg: 0.58, Zn: 0.04, Al: balance (4R), were produced using a 400 tons HPDC machine that was equipped with an automated RheoMetal ${ }^{\mathrm{TM}}$ slurry generator. RheoMetal $^{\mathrm{TM}}$ exploits an Enthalpy Exchange Material (EEM) as an internal cooling agent to generate the slurry. The 
die utilized included two halves: a fixed and a moving half. The temperature of the fixed half was set between 230$250{ }^{\circ} \mathrm{C}$ while the temperature of the moving half was set between $280-320^{\circ} \mathrm{C}$. The holding furnace temperature was fixed at $675{ }^{\circ} \mathrm{C}$. The shot weight was approximately $5 \mathrm{~kg}$ and ladling was performed using a standard cast iron ladle to which the EEM was added (5-6\% of the shot weight). The stirring rate used was $900 \mathrm{rpm}$ and the slurry solid fraction was about $40 \%$. The final slurry temperature was then set at $610 \pm 1{ }^{\circ} \mathrm{C}$. The die cavity fill-time was $31 \mathrm{~ms}$ while the first stage and the second stage piston speed were 0.23 and $5.2 \mathrm{~m} / \mathrm{s}$, respectively. These conditions were similar to standard settings for this type of component under normal HPDC processing. The studied component is an experimental cavity filter demonstrator resembling the real component used in telecom base stations. We have studied the microstructural and electrochemical features of these Al-Si alloy components in our previous work [45].

\subsection{Cerium conversion process}

Samples of the two alloys were cut into pieces of $1 \mathrm{~cm} \times 1 \mathrm{~cm}$ and ground using $\mathrm{SiC}$ abrasive papers of P1200 and P4000. These samples were then rinsed and ultrasonically cleaned in acetone for 10 minutes. The alkaline activation step included etching in $40 \mathrm{~g} / \mathrm{l} \mathrm{NaOH}$ solution for 15 seconds. Between each of these steps, samples were rinsed with deionized water and then dried. Conversion treated samples were then dried and kept in a desiccator for further microstructural and electrochemical testing. Conversion solutions were made from analytical grade hydrated cerium nitride $\left(\mathrm{Ce}\left(\mathrm{NO}_{3}\right)_{3} \cdot 6 \mathrm{H}_{2} \mathrm{O}\right)$, sodium chloride $(\mathrm{NaCl})$, and hydrogen peroxide $\left(\mathrm{H}_{2} \mathrm{O}_{2}\right)$. Before immersion of the samples, all the solutions were aged for at least 30 minutes so that the cerium species reached the equilibrium. Details of the solutions chemistry and immersion times are presented in Table. 1.

\subsection{Layers characterization}

Microstructural features of the cerium-based conversion coatings were examined by Scanning Electron Microscopy (SEM, JSM-IT300), under high vacuum conditions with $20 \mathrm{kV}$ beam energy Energy-dispersive X-ray spectroscopy (EDXS) was exploited to measure the composition of the conversion layers and to collect the elemental map of $\mathrm{Al}$, $\mathrm{Si}, \mathrm{Fe}, \mathrm{Ce}$ and OA LYRA3 FIB/SEM was used for cross sectioning and analyses the treated surfaces. The FIB milling conditions were as follows: $30 \mathrm{kV}, 5 \mathrm{nA}$ for rough milling and $1 \mathrm{nA}$ for final polishing. In this case, beam energy of 15 $\mathrm{kV}$ was employed. For EDAX/EDS analysis 254 frames mapping and $50 \mu \mathrm{s}$ dwell time were utilized.

The surface state of conversion treated samples were analysed using X-ray photoemission spectroscopy (XPS). The analysis was carried out using an Axis DLD Ultra instrument (Kratos-Manchester UK). Acquisitions were composed by wide scans on a BE energy range of $1250--5 \mathrm{eV}$ using a $160 \mathrm{eV}$ pass energy. High-resolution core line spectra was performed by setting the analyser pass energy at $20 \mathrm{eV}$ and the energy step at $0.05 \mathrm{eV}$. When necessary, charge compensation was utilized on samples with scarce conductivity. Compensation was optimized by maximizing the peak intensity and minimizing the peak full width at half maximum of the main core line peaks. C $1 \mathrm{~s}$ from contaminants at $285 \mathrm{eV}$ was selected as a reference for energy scale alignment. The final energy resolution was $\sim 0.35$ 
$\mathrm{eV}$. The analysis of the XPS spectra was performed using a home-made software based on the R platform. Care was taken when selecting the appropriate background subtraction and Gaussian components for peak fitting.

The electrochemical behavior and the corrosion resistance of $\mathrm{CeCC}$ treated $\mathrm{Al}-\mathrm{Si}$ alloys were examined in a $0.05 \mathrm{M}$ $\mathrm{NaCl}$ solution by potentiodynamic polarization and electrochemical impedance spectroscopy (EIS). A traditional three electrode cell was exploited including the sample as the working electrode (with the exposure area of $1 \mathrm{~cm}^{2}$ ), a platinum electrode as the counter electrode and a silver/silver chloride electrode ( $\mathrm{Ag} / \mathrm{AgCl} 3 \mathrm{M} \mathrm{KCl}(0.210 \mathrm{~V}$ vs $\mathrm{NHE})$ as the reference electrode. All the electrochecal tests were monitored by a computer-controlled potentiostat (Metrohm Autolab PGSTAT302N). In the polarization test, the sweep rate of $0.166 \mathrm{mV} / \mathrm{s}$ and the initial delay of 10 minutes were set. Cathodic and anodic branches were collected separately, starting from the open circuit potential (OCP) in both cases. Anodic and cathodic polarizations were stopped after the maximum current densities of $9 \times 10^{-4} \mathrm{~A} / \mathrm{cm}^{2}$ and $4 \times 10^{-5} \mathrm{~A} / \mathrm{cm}^{2}$ were reached, respectively. In the EIS tests, frequency ranged from $100 \mathrm{kHz}$ to $10 \mathrm{mHz}$ with 36 points/decade and the amplitude of the sinusoidal potential signal was $10 \mathrm{mV}$ with respect to the OCP. To guarantee the reliability of the data, the electrochemical tests were repeated at least three times. Moreover, to compare the results, all the electrochemical tests were conducted also on bare $2 \mathrm{R}$ and $4 \mathrm{R}$ alloys.

\section{Result}

\subsection{Morphology and composition}

Fig. 1 depicts the microstructure of two Al-Si alloys substrates processed using Rheo-HPDC method. As it can be seen in these images, the microstructure of semi-solid cast Al-Si alloy contains primary $\alpha$-Al particles in two different sizes, Al-Si eutectic dual phase region, and iron-rich needle shape intermetallic particles ( $\beta$-AlFeSi). SEM image at higher magnification (Fig. 1 (b)) shows that the location of the intermetallic particles is mainly the eutectic region. Formation of two different range sizes of $\alpha$-Al phase is attributed to the two-stage solidification in the semi-solid metal process. The formation of coarser $\alpha$-Al particles $\left(\alpha_{1}-\mathrm{Al}\right)$ is related to the nucleation during slurry preparation, while finer particles $\left(\alpha_{2}-\mathrm{Al}\right)$ are formed during the second solidification stage inside the cavity with high cooling rate and the absence of shear force [46].

Fig. 2 shows the primary conversion coatings deposited from solutions of different $\mathrm{Ce}\left(\mathrm{NO}_{3}\right)_{3}$ concentrations on the alloy with 2.5 wt.\% Si. According to the images in Fig. 2, cerium hydroxide/oxide deposition (white islands in the backscattered SEM images) is or has been started locally. It can be observed that the amount of cerium-based precipitates is higher on the eutectic region and/or the iron-rich IM particles inside them. the deposition of the conversion layer increases as the concentration of $\mathrm{Ce}\left(\mathrm{NO}_{3}\right)_{3}$ increases. It is noticeable that the background matrix of the conversion coating is less visible in the case of samples treated using the solutions of 0.01 and $0.05 \mathrm{~mol} / 1 \mathrm{Ce}\left(\mathrm{NO}_{3}\right)_{3}$, while in the sample immersed in the solution of $0.1 \mathrm{~mol} / \mathrm{Ce}\left(\mathrm{NO}_{3}\right)_{3}$, the presence of background matrix is easily detectable, especially due to its cracked structure. According to the literature $[4,8]$, this means that the deposition of cerium hydroxide/oxide layer starts from the cathodic sites but it grows further to cover the entire aluminium alloy surface [12]. In Fig. 2 (b), SEM image from a cerium-based nuclei at a higher magnification shows this lateral growth. Higher $\mathrm{Ce}\left(\mathrm{NO}_{3}\right)_{3}$ concentration provides more cerium ions required for the precipitation since their numbers are reduced due to the formation of stable cerium nitrate complexes such as $\mathrm{Ce}\left(\mathrm{NO}_{3}\right)_{5}{ }^{2-}$ and $\mathrm{Ce}\left(\mathrm{NO}_{3}\right)_{6}{ }^{3-}$ [47]. These stable complexes result from the oxygen-donor ligand and cerium cation interactions [48]. 
In these series of treated substrates, no significant difference can be observed on the degree of cerium deposition over $\alpha_{1}-\mathrm{Al}$ and $\alpha_{2}$ - $\mathrm{Al}$ particles. As expected, not all eutectic region are covered by the $\mathrm{CeCC}$ and therefore not all of them were cathodically activated

The effect of the addition of chloride ions and/or hydrogen peroxide to the solution on the morphology of the CeCC layers on 2R alloy is presented in SEM images of Fig. 3. Considering Fig. 3 (a), with $0.1 \mathrm{~mol} / 1 \mathrm{NaCl}$, higher amount of cerium compounds depositions is observed. This coating shows some differences in comparison to the coating deposited from the same solution without $\mathrm{NaCl}$ (Fig. 2(b)). In presence of $\mathrm{NaCl}$, the primary $\alpha$-Al particles $\left(\alpha_{1}\right.$ - $\mathrm{Al}$ ) show less coverage of $\mathrm{CeCC}$ (or a thinner layer) on their surfaces compared to $\alpha_{2}$ - $\mathrm{Al}$ or compared to samples without $\mathrm{NaCl}$. SEM image of this coating at a higher magnification and the results of EDXS analysis confirm this phenomenon (Fig. 4).

Chloride ions in the conversion solution have an accelerating effect on the precipitation of cerium hydroxide/oxide. They can break the native aluminium oxide layer on the alloy surface and accelerate and activate the corrosion reactions (anodic and cathodic) on the micro-galvanic couples, formed in the eutectic regions [45]. This eads to higher $\mathrm{pH}$ and therefore more cerium hydroxide deposition [33, 49]. In this condition, $\mathrm{CeCC}$ deposition process is faster resulting in a thicker coating [33]. Nitrate ions are not able to breakdown the aluminium oxide and they also passivate the surface of aluminium alloys by incorporation into the oxide [22, 51, 52], therefore a faster deposition is expecting in the presence on $\mathrm{Cl}$ ions compared to the plain Ce solution

Moreover, the activating effect of the chloride ions highlights the difference between the two different $\alpha$-Al phases. $\alpha_{1}$-Al particles are less covered compared to $\alpha_{2}$-Al particles, resulting in heterogeneous deposition of the conversion layer due to the different activity. The results of WDS analysis of these grains show that they differ in ththe Si content in solution in the $\mathrm{Al}$ : $\alpha_{2}$ - $\mathrm{Al}$ grains containhigher silicon in comparison to $\alpha_{1}$ - $\mathrm{Al}$ ones [46]. The higher level of silicon in the $\alpha_{2}$-Al phase contributes to increase its potential toward more cathodic values [53]. Moreover the size of the grains makes the $\alpha_{2}$-Al grains closer and more interacting with the Si and Fe-rich IM and therefore easier to be covered. The presence of chloride ions in the conversion solution can also affect the valence state of cerium. The equilibrium potential of oxidation reaction of Ce (III) to Ce (IV) is sensitive to the anions present in the solution:

$\mathrm{Ce}^{3+}+2 \mathrm{H}_{2} \mathrm{O} \leftrightarrow \mathrm{Ce}(\mathrm{OH})_{2}{ }^{2+}+2 \mathrm{H}^{+}+\mathrm{e}^{-}$

The chloride ions decrease the equilibrium potential by $400 \mathrm{mV}$ allowing the oxidation reaction to take place more easily [48].

Hydrogen peroxide can be added to the conversion solution to act as an oxidizing agent and therefore have a more homogenous deposit The presence of hydrogen peroxide, either alone or together with chloride ions increases the deposition rate and the thickness of the conversion layer, resulting in the formation of a conversion layer with crackedmud structure (Figs. 3 (b) and (c)). This feature is due to the stresses induced in the coating during the drying step [11]. By adding the $\mathrm{H}_{2} \mathrm{O}_{2}$, the entire surface is covered by the conversion layer. However, some heterogeneities are still visible on the coating surface in which $\alpha_{1}$-Al particles result to be covered by a thinner deposit. 
In the deposition of Ce-based conversion layer hydrogen peroxides acts as a complexing agent, an oxidant, a crystallization inhibitor, and a source of $\mathrm{OH}^{-}$ions [54]. Reduction of hydrogen peroxide on the cathodic areas provides a source of hydroxyl ions (Reaction 2). Hydrogen peroxide also oxidizes $\mathrm{Ce}^{3+}$ ions to $\mathrm{Ce}^{4+}$ by the formation of a complex [54, 55]:

$2 \mathrm{Ce}^{3+}+\mathrm{H}_{2} \mathrm{O}_{2}+2 \mathrm{OH}^{-} \leftrightarrow 2 \mathrm{Ce}(\mathrm{OH})_{2}{ }^{2+}$

The literature reports that these conditions lead to the formation of a hydroxide/oxide coating containing mainly $\mathrm{Ce}$ (IV) species $[54,55]$.

The conversion layers deposited on 4R alloy from the solutions containing chloride ions (Fig. 5 (a)), hydrogen peroxide (Fig. 5 (b)), and chloride ions together with hydrogen peroxide (Fig. 5(c)), have similar characteristics to those on $2 \mathrm{R}$ alloy. The heterogeneity related to the thinner deposition over $\alpha_{1}$-Al particles is detectable especially in the conversion coating deposited from the solution of $0.05 \mathrm{~mol} / \mathrm{l} \mathrm{Ce}\left(\mathrm{NO}_{3}\right)_{3}$ and $0.1 \mathrm{~mol} / \mathrm{l} \mathrm{NaCl}$ (Fig. 5 (a)). The addition of hydrogen leadsto a thick cracked coating all over the surface (Figs. 5 (b) and (c)). This coating is also heterogeneous in some parts as it can be seen in Fig. 5 (b). The surface morphology of the Ce-based layer deposited from a combination of chloride ions and hydrogen peroxide, contains Ce-rich nodules over the cracked background matrix.

Understanding the formation mechanism of the cerium-based conversion layer is possible by looking at the crosssectional view of the local cerium-based precipitates. Fig. 6 provides this view for the conversion coating on $2 \mathrm{R}$ alloy, immersed in $0.05 \mathrm{~mol} / \mathrm{l} \mathrm{Ce}\left(\mathrm{NO}_{3}\right)_{3}$ for 18 hours. The elemental maps of $\mathrm{Al}, \mathrm{Si}, \mathrm{Fe}, \mathrm{Ce}$, and $\mathrm{O}$ are also provided in this figure. These images depict the presence of an iron-rich IM particle located inside the eutectic region, which is detectable through the elemental map of Si (Fig. 6(c)). It can be observed that the formation of the cerium-based layer started from the iron-rich IM particle. In addition, a cavity is visible under the cerium-based nuclei where the IM particle is located. The presence of this cavity is due to the corrosion process and is the result ofthe dissolution of aluminium phase in the eutectic region. It is worth mentioning that many cerium-based precipitates were checked and a cavity was always seen underneath each of them. . According to the elemental map of O (Fig. 6 (f)), there is also oxide inside the cavity proving that it was the result of an oxidation pedation.

SEM image and the elemental maps from the cross-sectional view of a Ce-based nuclei on $2 \mathrm{R}$ alloy treated in 0.05 $\mathrm{mol} / \mathrm{Ce}\left(\mathrm{NO}_{3}\right)_{3}$ and $0.1 \mathrm{~mol} / 1 \mathrm{NaCl}$ for 18 hours are depicted in Fig. 7. The interesting phenomenon captured in this image is the oxidation of the IM particle, which can be seen through the oxygen mapping in Fig. 7 (f). The oxide seems to fill the cavity that was formed in the previous step. In the presence of chloride ions in the conversion solution, anodic and cathodic reactions are promoted and accelerated. After $\mathrm{Al}$ dissolution from $\mathrm{Al}$ phase, another process that can occur is the selective dissolution of aluminium from the IM particle that makes it richer in iron and silicon [56]. Considering the OCP of this system ( - - $0.6 \mathrm{~V}), \mathrm{pH}$ of the solution (4.4), and according to Pourbaix diagram of iron [57], oxidation of iron is not thermodynamically possible. However, cathodic reactions increase the $\mathrm{pH}$ locally high enough for the possible formation of iron oxide when all the $\mathrm{Al}$ has dissolved. The extension of iron oxidation is visible in the SEM image and EDXS results taken after removing the conversion layer as shown in Fig. 8. Upon oxidation of iron, the particle becomes more cathodic [56], therefore, more suitable for the cathodic reactions. The 
very first layer of the cerium-based nuclei seems to be richer in cerium compounds as it appears whiter in the backscattered image (Fig. 7 (a)). The rest of the coating can be assumed to be a mixture of cerium hydroxide/oxide and aluminium oxide.

Fig. 9 presents the proposed formation mechanism of the cerium-based conversion layer. The presence of iron-rich IM particles is the main reason of the deposition of the conversion layer on the Al-Si alloy. According to our results, the formation mechanism includes three steps:

1. Dissolution of aluminium phase next to an iron-rich IM particle until there is no connection between the IM particle and the aluminium matrix. The cathodic reactions are localized on the IM raising the $\mathrm{pH}$ and triggering the cerium hydroxide/oxide deposition.

2. Selective dissolution of aluminium from the IM particle and then oxidation of the remained iron. The dissolution of aluminium from the iron-rich IM particle can occur according to the following reaction [58]:

$$
2 \mathrm{Al}+2 \mathrm{OH}^{-}+6 \mathrm{H}_{2} \mathrm{O} \rightarrow 2 \mathrm{Al}(\mathrm{OH})^{-}{ }_{4}^{-}+3 \mathrm{H}_{2}
$$

The iron oxide fills the cavity that was formed due to the dissolution of aluminium in the previous step. Cerium deposition continues during this step.

3. Growth of the existing cerium hydroxide/oxide nuclei and start of a later growth.

Results of XPS analysis of 2R alloy treated using three different solutions (including the solution of $0.05 \mathrm{~mol} / \mathrm{l}$ $\mathrm{Ce}\left(\mathrm{NO}_{3}\right)_{3}$, the solution of $0.05 \mathrm{Ce}\left(\mathrm{NO}_{3}\right)_{3}$ and $0.1 \mathrm{~mol} / 1 \mathrm{NaCl}$, and the solution of $0.05 \mathrm{~mol} / 1 \mathrm{Ce}\left(\mathrm{NO}_{3}\right)_{3}$ and $0.02 \mathrm{~mol} / 1$ $\mathrm{H}_{2} \mathrm{O}_{2}$ ) are illustrated in Figs. 10 (a), (b) and (c) respectively. In each of the XPS spectrum, a peak of carbon is also noticeable. This peak is attributed to the accumulation of contaminants on the surface due to exposure to air, which has also been observed and reported before by other researchers [9]. It can be also due to the dye releasing agent which is entrapped in the very first solidification layer of the aluminium alloy surface during casting. This was proved by XPS spectra of bare aluminium alloys were carbon peak was present in all the specimens

The analysed cerium-based conversion coatings presented a mixture of Ce (III) and Ce (IV) compounds. The interpretation of the Ce $3 \mathrm{~d}$ core line was made a long time ago by Burroughs et al. [59]. In this case, the more recent work of Romeo et al. [60] can be also referred. Ce (IV) and Ce (III) in their ground state possess a $4 \mathrm{f}^{0}$ and $4 \mathrm{f}^{1}$ orbital, respectively. When an $\mathrm{X}$ photon creates a hole in the $3 \mathrm{~d}$ level a rearrangement of the cerium electronic structure in the valence band occurs. In particular, the $4 \mathrm{f}$ orbital is pulled away from the Fermi into the valence band to screen the $3 \mathrm{~d}$ hole. This in presence of $\mathrm{Ce}$ (IV) or Ce (III) oxides or hydroxides leads to a strong hybridization of the cerium ground state $4 \mathrm{f}^{0}$ with the $2 \mathrm{p}$ oxygen orbital. Concerning the analysis, the Ce $3 \mathrm{~d}$ core line appears as doublets in XPS spectra due to the spin orbit splitting. The energy of the photo-emitted $3 \mathrm{~d}$ electron will depend on the coupling between the initial $3 \mathrm{~d}$ and $4 \mathrm{f}$ hybridized orbital. The result of this coupling is that in the case of Ce (IV) the $3 \mathrm{~d}_{5 / 2}$ level will show three components while the same orbital in Ce (III) will be composed of two features. Then the description of the Ce $3 \mathrm{~d}$ core line in presence of both the Ce (III) and Ce (IV) will need a total of 10 fitting components. Here the component assignment and nomenclature is done in agreement with the work of Burroughs et al. [59]: $\mathrm{v}, \mathrm{v}$ " and v" ", are associated to Ce (IV). The first two derived from a mixture of $(5 \mathrm{~d} 6 \mathrm{~s})^{0} 4 \mathrm{f}^{2} \mathrm{O} 2 \mathrm{p}^{4}$ and $(5 \mathrm{~s} 6 \mathrm{~d})^{\prime} 4 \mathrm{f}^{1} \mathrm{O} 2 \mathrm{p}^{5}$ orbitals, while $\mathrm{v}^{\prime \prime}$ ' is 
associated to $(5 \mathrm{~d} 6 \mathrm{~s})^{0} 4 \mathrm{f}^{0} \mathrm{O} 2 \mathrm{p}^{6}[60]$. Features derived from Ce (III) are indicated with $\mathrm{v}_{0}$ and $\mathrm{v}^{\prime}$ and are generated by mixing $(5 d 6 s)^{0} 4 f^{2} \mathrm{O} 2 p^{4}$ and $(5 d 6 s)^{0} 4 f^{1} \mathrm{O} 2 p^{5}$ orbitals. A list of correspondent components is presented for the $3 d_{3 / 2}$ using the letter $\mathrm{u}$ and the same indexes. $\mathrm{u}$ and $\mathrm{v}$ components are separated by the spin orbit splitting energy which for cerium is $\sim 18.3 \mathrm{eV}$. A summary of results for the coatings deposited from the different conversion solutions is presented in Table. 2. The ratio of Ce (III)/Ce (IV) (in forms of oxide and/or hydroxide) is 0.86 for the conversion layer from the plain solution (with only $\left.0.05 \mathrm{~mol} / \mathrm{l} \mathrm{Ce}\left(\mathrm{NO}_{3}\right)_{3}\right), 0.79$ for the layer deposited from the solution with chloride ions, and 0.55 for the coating deposited from the solution containing hydrogen peroxide. As expected, the presence of chloride ions and hydrogen peroxide increases the fraction of Ce (IV) species in the coatings. Hydrogen peroxide affects by oxidizing $\mathrm{Ce}^{3+}$ while chloride ions by decreasing the equilibrium potential of the oxidation reaction of $\mathrm{Ce}^{3+}$ to $\mathrm{Ce}^{4+}$. $\mathrm{Ce}$ (III) species are shown to be concentrated in the inner layer of the conversion coating, while $\mathrm{Ce}$ (IV) species are mostly located in the outer layer of the coating [9, 61]. Considering oxygen peaks (high resolution peaks in Figs. 10 (g), (h) and (i)), the peaks centred at $531.49 \mathrm{eV}, 532.14 \mathrm{eV}$, and $530.62 \mathrm{eV}$ are ascribable to aluminium oxide $\left(\mathrm{Al}_{2} \mathrm{O}_{3}\right)$ [61]. While the shoulders at $529.23 \mathrm{eV}, 530.29 \mathrm{eV}, 529.67 \mathrm{eV}, 530.49 \mathrm{eV}, 529.37 \mathrm{eV}$, and $530.62 \mathrm{eV}$ can be attributed to the presence of $\mathrm{CeO}_{2}$ and $\mathrm{Ce}_{2} \mathrm{O}_{3}$, respectively. Aluminium oxide $\left(\mathrm{Al}_{2} \mathrm{O}_{3}\right)$ percentages vary from $16 \%$ in the conversion coating from the plain solution to $16.5 \%$ for the layer deposited from the solution with chloride ions and to $4 \%$ for the coating deposited from the solution containing hydrogen peroxide. This obviously indicates the higher thickness of the cerium-based layer in the case of the conversion coating deposited using the hydrogen peroxide solution.

The presence of hydrogen peroxide in the conversion solution also changes the response of $\mathrm{Al}_{2} \mathrm{O}_{3}$, in which the sample treated using the solution of $0.05 \mathrm{~mol} / \mathrm{Ce}\left(\mathrm{NO}_{3}\right)_{3}$ and $0.02 \mathrm{~mol} / 1 \mathrm{H}_{2} \mathrm{O}_{2}$ shows a significant difference in $\mathrm{O} 1 \mathrm{~s}$ binding energy compared to the other two samples. In addition, in oxygen peak in Fig. 10 (i), there is a component at low binding energy whose essence is still unclear.

\subsection{Electrochemical properties}

Fig. 11 depicts the results of EIS test on the samples of $2 \mathrm{R}$ alloy treated using different conversion solutions. It presents the impedance spectra after 6 and 24 hours of immersion in $\mathrm{NaCl}$ solution of $0.05 \mathrm{~mol} / \mathrm{l}$. The impedance values for all the systems during 24 hours are quite stable. Regarding the effect of $\mathrm{Ce}\left(\mathrm{NO}_{3}\right)_{3}$ concentration (Figs. 11 (a) and (d)), all the conversion layers possess higher impedance values at low frequency compared to the bare aluminium alloy. The low-frequency impedance modulus valueis an estimate of the total resistance of the system [6]. As it is obvious from Fig. 11 (a) and (d), these values are increased by more than one order of magnitude for the treated samples compared to the bare aluminium alloy. This improvement is due to the presence of cerium-based conversion layer which especially passivates iron-rich IM particles located inside the eutectic regionsPassivating these phases hinders the microgalvanic couple and therefore the corrosion process. Some scattered points at low frequencies are observed in the values of $|\mathrm{Z}|$ of the conversion layer obtained from the solution of $0.1 \mathrm{~mol} / \mathrm{l} \mathrm{Ce}\left(\mathrm{NO}_{3}\right)_{3}$. In general, in these set of results, the best corrosion performance is related to the conversion layer deposited from the solution of $0.05 \mathrm{~mol} / \mathrm{l} \mathrm{Ce}\left(\mathrm{NO}_{3}\right)_{3}$. As $\mathrm{Ce}\left(\mathrm{NO}_{3}\right)_{3}$ concentration increases so does the deposition extent and the thickness of the 
conversion layer. However, it seems that if the concentration of $\mathrm{Ce}\left(\mathrm{NO}_{3}\right)_{3}$ is too high the deposited layer will develop cracks and therefore decrease its protection (Fig. 2 (c)) .

The addition of different concentrations of $\mathrm{NaCl}$ to the conversion solution also produces coatings with higher impedance values in comparison to the bare aluminium substrate.

However, according to the results shown in Fig. 11 (b) and (e), none of the conversion coatings deposited from $\mathrm{NaCl}$ containing solutions shows higher impedance values compared to those of the coating from the plain $\mathrm{Ce}\left(\mathrm{NO}_{3}\right)_{3}$ solution. For comparison, the results related to the coating deposited from the conversion solution of $0.05 \mathrm{~mol} / \mathrm{l}$ $\mathrm{Ce}\left(\mathrm{NO}_{3}\right)_{3}$ (the optimum concentration) are presented in these graphs as well. This can depict the detrimental effect of chloride ions, in the conversion solution, on the corrosion resistance of the aluminium substrate. In addition, a high concentration of $\mathrm{NaCl}(0.1 \mathrm{~mol} / \mathrm{l})$ results in the deposition of a thicker conversion layer (Fig. 3(a)) which again suffers from the cracked morphology. By comparing the results related to the two optimum coatings with and without 0.05 $\mathrm{mol} / \mathrm{l} \mathrm{NaClit}$ can be seen that the conversion layer deposited from $\mathrm{NaCl}$ containing solution shows higher impedance values compared to the one deposited from the plain conversion solution after 6 hours of EIS test Fig. 11 (b). However, at the end of the 24 hours test Fig. 11 (e), the coating deposited from the chloride free conversion solution possesses higher impedance values at low frequencies. The relatively lower corrosion resistance of the conversion layers deposited using $\mathrm{NaCl}$ containing solution can be a result of heterogeneous deposition, in which $\alpha_{1}$ - $\mathrm{Al}$ particles are covered by a thinner conversion layer.

Hydrogen peroxide was added to the conversion solution (alone or together with $\mathrm{NaCl}$ (Fig. 12)) to shorten the required time for the conversion process and to obtain homogenously deposited coatings (Figs. 11 (c) and (f) and Fig. 12). . Regarding the coatings deposited from the mix solution (Fig. 12), only 20 minutes of immersion is enough to achieve higher values of the total impedance, compared to the bare aluminium alloy while 60 minutes of immersion deteriorates the corrosion properties. This is attributed to the fact that the combination of chloride ions and hydrogen peroxide canbe very agressive and cause subsurface crevices [33]. In addition, the coating deposited from this combination after longer immersion time is thicker and have a morphology full of cracks. The conversion solution of $0.05 \mathrm{~mol} / \mathrm{l} \mathrm{Ce}\left(\mathrm{NO}_{3}\right)_{3}$ and $0.02 \mathrm{~mol} / 1 \mathrm{H}_{2} \mathrm{O}_{2}$ produces a coating with improved corrosion resistance after both 20 and 60 minutes immersion (Figs. 11 (c) and (f)). This improvement is comparable to the conversion layer deposited from the solution of $0.05 \mathrm{~mol} / 1 \mathrm{Ce}\left(\mathrm{NO}_{3}\right)_{3}$, while the required process time has shortened from 18 hours to only 1 hour. However, it should be noted that the selectively deposited coating from the plain conversion solution (with optimum concentration of $\left.\mathrm{Ce}\left(\mathrm{NO}_{3}\right)_{3}\right)$ still shows higher corrosion resistance.

The results of EIS measurements related to the treated samples of 4R alloy are shown in Figs. 13 and 14. These samples were treated with the same conversion solutions presented in Figs. 11 and 12. The samples were also treated using a solution with lower concentration of sodium chloride mixed with hydrogen peroxide $\left(0.05 \mathrm{~mol} / \mathrm{l} \mathrm{Ce}\left(\mathrm{NO}_{3}\right)_{3}\right.$, $0.01 \mathrm{~mol} / \mathrm{l} \mathrm{NaCl}$, and $\left.0.02 \mathrm{~mol} / 1 \mathrm{H}_{2} \mathrm{O}_{2}\right)$ and also a solution with lower concentration of hydrogen peroxide $(0.05 \mathrm{~mol} / \mathrm{l}$ $\mathrm{Ce}\left(\mathrm{NO}_{3}\right)_{3}$ and $\left.0.01 \mathrm{~mol} / 1 \mathrm{H}_{2} \mathrm{O}_{2}\right)$.

First of all, the bare Al- 4.5 wt.\% Si show higher total impedance values compared to those of Al- $2.5 \mathrm{wt} . \% \mathrm{Si}$. In fact, other researches on the corrosion behavior of Al-Si alloys have all indicated the positive effect of silicon on the corrosion resistance of the aluminium alloys [62-64]. The higher corrosion resistance of alloys with higher silicon 
content has been partly attributed to the incorporation of silicon atoms to the passive film, which repairs the film defects and renders it more stable [62, 65].

Regarding the treated samples using the plain $\mathrm{Ce}\left(\mathrm{NO}_{3}\right)_{3}$ solutions (Figs. 13 (a) and (d)), all the samples show almost the same extent of improvement in the total impedance values compared to the bare aluminium alloy substrate. It seems that the surface of Al-Si alloy with $4.5 \mathrm{wt}$.\% Si have enough active cathodic sites for the oxygen reduction to occur leading to $\mathrm{pH}$ increase and the deposition of cerium hydroxide/oxide layers, even when the substrates are immersed in low concentrated solutions of $\mathrm{Ce}\left(\mathrm{NO}_{3}\right)_{3}$. As it can be seen, the negative effect of high concentration of $\mathrm{Ce}\left(\mathrm{NO}_{3}\right)_{3}$ is negligible, unlike the similar $2 \mathrm{R}$ treated samples. A decrease in the values of $|\mathrm{Z}|$ at low and medium frequencies can be observed for the untreated sample after 24 hours of EIS test. However, values of the total impedance of treated substrates remain considerably high even after 24 hours of immersion in $\mathrm{NaCl}$ solution of $0.05 \mathrm{~mol} / \mathrm{l}$.

By adding the proper concentration of chloride ions to the conversion solution, cerium-based layers with improved total impedance values are achieved. According to Figs. 13 (b) and (e), the highest total impedance values among the coatings deposited from chloride ions containing solutions belongs to the coating deposited from the solution containing $0.01 \mathrm{~mol} / \mathrm{l} \mathrm{NaCl}$. This shows that the surface of Al-Si alloy with a higher Si content needs lower concentrations of chloride ions for its cathodic sites to get activated. The values of the total impedance of this coating are similar to the one from $\mathrm{NaCl}$ free solution, especially after 24 hours of EIS test. In this case, the higher concentration of $\mathrm{NaCl}$ in the conversion solution $(0.05$ and $0.1 \mathrm{~mol} / \mathrm{l})$ results in poor corrosion resistance.

Results regarding $4 \mathrm{R}$ alloy samples treated using more oxidizing solutions (solutions containing hydrogen peroxide and the mix solutions) are presented in Figs. 13 (c) and (f) and Fig. 14. According to these curves, almost all the solutions are too aggressive for the samples of $4 \mathrm{R}$ alloy. They produce thick and cracked conversion layers without a significant improvement in the corrosion resistance.

In the mix solution (Fig. 14), sodium chloride concentration was reduced to the optimum concentration of $0.01 \mathrm{~mol} / \mathrm{l}$ and in the solution of $\mathrm{Ce}\left(\mathrm{NO}_{3}\right)_{3}$ and $\mathrm{H}_{2} \mathrm{O}_{2}$, the concentration of hydrogen peroxide was reduced to $0.01 \mathrm{~mol} / \mathrm{l}$. However, the only treated sample which showed improved corrosion resistance was the one immersed in the solution of $0.05 \mathrm{~mol} / \mathrm{l} \mathrm{Ce}\left(\mathrm{NO}_{3}\right)_{3}$ and $0.02 \mathrm{~mol} / 1 \mathrm{H}_{2} \mathrm{O}_{2}$ for 60 minutes. All the other samples of these sets showed weaker or equal corrosion resistance to that of the bare aluminum alloy. Fig. 15 depicts SEM image of the corroded surface of one of the mentioned set of conversion treated substrates. According to this image, the corrosive solution has permeated through the cracked coating resulting in intense corrosion. Here we can again conclude that the selectively deposited coatings from the plain conversion solutions possess higher corrosion resistance compared to that of the thick, cracked, and homogenously deposited coatings.

Results of the potentiodynamic polarization test in $\mathrm{NaCl}$ solution of $0.05 \mathrm{~mol} / \mathrm{l}$ for samples of $2 \mathrm{R}$ and $4 \mathrm{R}$ alloys treated under optimum conversion conditions are presented in Fig. 16. The results of the polarization test related to the bare $2 \mathrm{R}$ and $4 \mathrm{R}$ alloys are presented as well. The alloy with higher silicon content shows a nobler corrosion potential and lower current densities in both anodic and cathodic branches. In the case of the treated samples of $2 \mathrm{R}$ alloy, both samples (treated using the plain $0.05 \mathrm{~mol} / \mathrm{C} \mathrm{Ce}\left(\mathrm{NO}_{3}\right)_{3}$ solution and hydrogen peroxide containing solution) show nobler corrosion potential in comparison to the bare $2 \mathrm{R}$ aluminium alloy. In the anodic branches, the sample treated using the plain solution $\left(0.05 \mathrm{~mol} / \mathrm{l} \mathrm{Ce}\left(\mathrm{NO}_{3}\right)_{3}\right)$ shows lower current density compared to those of the conversion 
layer from the solution of $0.05 \mathrm{~mol} / \mathrm{l} \mathrm{Ce}\left(\mathrm{NO}_{3}\right)_{3}$ and $0.02 \mathrm{~mol} / 1 \mathrm{H}_{2} \mathrm{O}_{2}$ and the bare $\mathrm{Al}-2.5 \mathrm{wt} . \% \mathrm{Si}$ alloy. This is probably attributed to the cracked morphology of the conversion coating deposited from hydrogen peroxide containing solution which lets permeation of the corrosive solution to the surface resulting in higher corrosion rates. Regarding the cathodic branches, both conversion layers show lower current densities compared to the untreated $2 \mathrm{R}$ aluminium alloy. This is attributed to the decreased oxygen reduction rate [6], which obviously shows the efficiency in passivating and blocking he cathodic Similar results can be observed for the treated Al- $4.5 \mathrm{wt}$ \% Si alloy.

\section{Conclusion}

Cerium based conversion coatings were successfully deposited on two Rheo-HPDC Al-Si alloys. According to the results, the chemistry of the conversion solution changes the coating morphology from locally and selectively deposited coating to a thick and cracked coating using the plain $\mathrm{Ce}\left(\mathrm{NO}_{3}\right)_{3}$ solution and $\mathrm{NaCl}$ and $\mathrm{H}_{2} \mathrm{O}_{2}$ containing solutions, respectively. The deposition of the conversion layer starts from iron-rich IM particles located inside the eutectic region. The formation mechanism of the coating includes dissolution of the aluminium matrix, and deposition of cerium hydroxide/oxide layer. When the process is very fast and aggressive, even selective dissolution of aluminium from the intermetallic particle, oxidation of iron on the surface of intermetallic particle is observed. The aluminium alloy with the higher amount of silicon shows more active surface during the conversion process which reduces the required concentration of $\mathrm{Ce}\left(\mathrm{NO}_{3}\right)_{3}$ but also makes it difficult to work with more aggressive solutions. Finally, the conversion treatment significantly increases the corrosion resistance of the aluminium alloys in which selectively deposited coating shows more improvement compared to the cracked, thick, and homogenously deposited coating.

\section{Acknowledgment}

The authors would like to thank COMPtech $\mathrm{AB}$, Sweden for the production of the component and the technical support.

\section{References}

[1] A.E. Hughes, J.D. Gorman, P.J.K. Paterson, The characterisation of Ce-Mo-based conversion coatings on Alalloys: Part I, Corros. Sci., 38 (1996) 1957-1976.

[2] G. HJ, L. PS, P. PF, R. BC, Lung cancer among workers in chromium chemical production., Am. J. Ind. Med., 38 (2000) 115-126.

[3] S.M. Cohen, Review: Replacements for Chromium Pretreatments on Aluminum, CORROSION, 51 (1995) 71-78.

[4] B. Hinton, D. Arnott, N. Ryan, Cerium conversion coatings for the corrosion protection of aluminum, Mater. Forum, 1986, pp. 162-173.

[5] B.R.W. Hinton, Corrosion inhibition with rare earth metal salts, J. Alloys Compd., 180 (1992) 15-25.

[6] M. Olivier, A. Lanzutti, C. Motte, L. Fedrizzi, Influence of oxidizing ability of the medium on the growth of lanthanide layers on galvanized steel, Corros. Sci., 52 (2010) 1428-1439.

[7] R.G. Buchheit, S.B. Mamidipally, P. Schmutz, H. Guan, Active Corrosion Protection in Ce-Modified Hydrotalcite Conversion Coatings, CORROSION, 58 (2002) 3-14. 
[8] Y. Xingwen, C. Chunan, Y. Zhiming, Z. Derui, Y. Zhongda, Study of double layer rare earth metal conversion coating on aluminum alloy LY12, Corros. Sci., 43 (2001) 1283-1294.

[9] X. Yu, G. Li, XPS study of cerium conversion coating on the anodized 2024 aluminum alloy, J. Alloys Compd., 364 (2004) 193-198.

[10] B. Hinton, D. Arnott, The characteristics of corrosion inhibiting films formed in the presence of rare earth cations, Microstruct. Sci., 17 (1989) 311-320.

[11] P. Campestrini, H. Terryn, A. Hovestad, J.H.W. de Wit, Formation of a cerium-based conversion coating on AA2024: relationship with the microstructure, Surf. Coat. Technol., 176 (2004) 365-381.

[12] F. Andreatta, M.E. Druart, A. Lanzutti, M. Lekka, D. Cossement, M.G. Olivier, L. Fedrizzi, Localized corrosion inhibition by cerium species on clad AA2024 aluminium alloy investigated by means of electrochemical micro-cell, Corros. Sci., 65 (2012) 376-386.

[13] D. Lau, A.M. Glenn, A.E. Hughes, F.H. Scholes, T.H. Muster, S.G. Hardin, Factors influencing the deposition of Ce-based conversion coatings, Part II: The role of localised reactions, Surf. Coat. Technol., 203 (2009) 2937-2945. [14] A.E. Hughes, J.D. Gorman, P.R. Miller, B.A. Sexton, P.J.K. Paterson, R.J. Taylor, Development of cerium-based conversion coatings on 2024-T3 Al alloy after rare-earth desmutting, Surf. Interface Anal., 36 (2004) 290-303.

[15] C. Wang, F. Jiang, F. Wang, Cerium Chemical Conversion Coating for Aluminum Alloy 2024-T3 and Its Corrosion Resistance, CORROSION, 60 (2004) 237-243.

[16] N. Birbilis, R.G. Buchheit, D.L. Ho, M. Forsythb, Inhibition of AA2024-T3 on a Phase-by-Phase Basis Using an Environmentally Benign Inhibitor, Cerium Dibutyl Phosphate, Electrochem. Solid-State Lett., 8 (2005) C180-C183

[17] L.E.M. Palomino, I.V. Aoki, H.G. de Melo, Microstructural and electrochemical characterization of Ce conversion layers formed on Al alloy 2024-T3 covered with Cu-rich smut, Electrochim. Acta, 51 (2006) 5943-5953. [18] C.M. Rangel, T.I. Paiva, P.P. da Luz, Conversion coating growth on 2024-T3 Al alloy. The effect of pretreatments, Surf. Coat. Technol., 202 (2008) 3396-3402.

[19] A. de Frutos, M.A. Arenas, Y. Liu, P. Skeldon, G.E. Thompson, J. de Damborenea, A. Conde, Influence of pretreatments in cerium conversion treatment of AA2024-T3 and 7075-T6 alloys, Surf. Coat. Technol., 202 (2008) 37973807.

[20] P.S. Jones, P. Yu, W.R. Pinc, M.J. O'Keefe, W.G. Fahrenholtz, T.J. O'Keefe, Spray Deposition of Cerium OxideBased Conversion Coatings on Al 2024-T3, Int. J. of Appl. Ceram. Technol., 5 (2008) 63-73.

[21] D.K. Heller, W.G. Fahrenholtz, M.J. O'Keefe, Effect of Phosphate Source on Post-Treatment of Cerium-Based Conversion Coatings on Al 2024-T3, J. Electrochem. Soc., 156 (2009) C400-C406

[22] W. Pinc, S. Maddela, M. O'Keefe, W. Fahrenholtz, Formation of subsurface crevices in aluminum alloy 2024-T3 during deposition of cerium-based conversion coatings, Surf. Coat. Technol., 204 (2010) 4095-4100.

[23] D.K. Heller, W.G. Fahrenholtz, M.J. O'Keefe, The effect of post-treatment time and temperature on ceriumbased conversion coatings on Al 2024-T3, Corros. Sci., 52 (2010) 360-368.

[24] H. Shi, E.-H. Han, F. Liu, Corrosion protection of aluminium alloy 2024-T3 in $0.05 \mathrm{M} \mathrm{NaCl}$ by cerium cinnamate, Corros. Sci., 53 (2011) 2374-2384. 
[25] D.K. Heller, W.G. Fahrenholtz, M.J. O'Keefe, Chemical and structural analyses of subsurface crevices formed during spontaneous deposition of cerium-based conversion coatings, Mater. Charact., 62 (2011) 1071-1075.

[26] A.C. Balaskas, M. Curioni, G.E. Thompson, Evaluation of Inhibitor Performance by Electrochemical Methods: Comparative Study of Nitrate Salts on AA 2024-T3, J. Electrochem. Soc., 161 (2014) C389-C394.

[27] L. Paussa, F. Andreatta, D. De Felicis, E. Bemporad, L. Fedrizzi, Investigation of AA2024-T3 surfaces modified by cerium compounds: A localized approach, Corros. Sci., 78 (2014) 215-222.

[28] L. Paussa, F. Andreatta, N.C. Rosero Navarro, A. Durán, L. Fedrizzi, Study of the effect of cerium nitrate on AA2024-T3 by means of electrochemical micro-cell technique, Electrochim. Acta, 70 (2012) 25-33.

[29] B.Y. Johnson, J. Edington, M.J. O'Keefe, Effect of coating parameters on the microstructure of cerium oxide conversion coatings, Mater. Sci. Eng., A, 361 (2003) 225-231.

[30] B.F. Rivera, B.Y. Johnson, M.J. O'Keefe, W.G. Fahrenholtz, Deposition and characterization of cerium oxide conversion coatings on aluminum alloy 7075-T6, Surf. Coat. Technol., 176 (2004) 349-356.

[31] B.Y. Johnson, J. Edington, A. Williams, M.J. O'Keefe, Microstructural characteristics of cerium oxide conversion coatings obtained by various aqueous deposition methods, Mater. Charact., 54 (2005) 41-48.

[32] S. Joshi, W.G. Fahrenholtz, M.J. O'Keefe, Effect of Humidity on Cerium-based Conversion Coatings on Al 7075T6, ECS Trans., 28 (2010) 217-228.

[33] S. Joshi, B.L. Treu, M.J. O’Keefe, W.G. Fahrenholtz, Characterization of Cerium-Based Conversion Coatings on Al 7075-T6 Deposited from Chloride and Nitrate Salt Solutions, J. Electrochem. Soc., 158 (2011) C88-C93

[34] S. Joshi, W.G. Fahrenholtz, M.J. O'Keefe, Alkaline activation of Al 7075-T6 for deposition of cerium-based conversion coatings, Surf. Coat. Technol., 205 (2011) 4312-4319.

[35] W.G. Fahrenholtz, M.J. O'Keefe, H. Zhou, J.T. Grant, Characterization of cerium-based conversion coatings for corrosion protection of aluminum alloys, Surf. Coat. Technol., 155 (2002) 208-213.

[36] S. Joshi, W.G. Fahrenholtz, M.J. O'Keefe, Effect of alkaline cleaning and activation on aluminum alloy 7075T6, Appl. Surf. Sci., 257 (2011) 1859-1863.

[37] A. Pardo, M.C. Merino, R. Arrabal, F. Viejo, M. Carboneras, Improvement of Corrosion Behavior of A3xx.x/SiCp Composites in 3.5 wt \% NaCl Solution by Ce Surface Coatings, J. Electrochem. Soc., 153 (2006) B52B60.

[38] A. Pardo, M.C. Merino, R. Arrabal, F. Viejo, J.A. Muñoz, Ce conversion and electrolysis surface treatments applied to A3xx.x alloys and A3xx.x/SiCp composites, Appl. Surf. Sci., 253 (2007) 3334-3344.

[39] F. Bonollo, N. Gramegna, G. Timelli, High-Pressure Die-Casting: Contradictions and Challenges, JOM, 67 (2015) 901-908.

[40] M. Qi, Y. Kang, B. Zhou, W. Liao, G. Zhu, Y. Li, W. Li, A forced convection stirring process for Rheo-HPDC aluminum and magnesium alloys, J. Mater. Process. Technol., 234 (2016) 353-367.

[41] S. Ji, Z. Zhen, Z. Fan, Effects of rheo-die casting process on the microstructure and mechanical properties of AM50 magnesium alloy, J. Mater. Sci. Technol., 21 (2005) 1019-1024.

[42] Z. Fan, S. Ji, G. Liu, Development of the Rheo-Diecasting Process for Mg-Alloys, Mater. Sci. Forum, 488-489 (2005) 405-412. 
[43] H. Moller, W.E. Stumpf, P.C. Pistorius, Influence of elevated Fe, Ni and Cr levels on tensile properties of SSMHPDC Al-Si-Mg alloy F357, Trans. Nonferrous Met. Soc. China, 20 (2010) s842-s846.

[44] C.K. Jin, C.H. Jang, C.G. Kang, Die design method for thin plates by indirect rheo-casting process and effect of die cavity friction and punch speed on microstructures and mechanical properties, J. Mater. Process. Technol., 224 (2015) 156-168.

[45] M. Eslami, F. Deflorian, M. Payandeh, A.E.W. Jarfors, C. Zanella, Investigation of corrosion behavior of SSMHPDC aluminum-silicon alloys, EuroCorr 2016, Montpellier, 2016.

[46] M. Payandeh, Rheocasting of Aluminium Alloys: Slurry Formation, Microstructure, and Properties, Department of Materials and Manufacturing, Jönköping University, 2015.

[47] S. Kiyota, B. Valdez, M. Stoytcheva, R. Zlatev, J.M. Bastidas, Anticorrosion behavior of conversion coatings obtained from unbuffered cerium salts solutions on AA6061-T6, J. Rare Earths, 29 (2011) 961-968.

[48] P. Campestrini, Microstructure-related quality of conversion coatings on aluminium alloys, Applied Sciences, Delft University, 2002.

[49] I. Aziz, Q. Zhang, M. Xiang, Using EIS to evaluate anti-corrosion properties of the SiCp/5A06 aluminium MMC treated by cerium conversion coatings, J. Rare Earths, 28 (2010) 109-116.

[50] B.L. Treu, S. Joshi, W.R. Pinc, M.J. O'Keefe, W.G. Fahrenholtz, Characterization of localized surface states of Al 7075-T6 during deposition of cerium-based conversion coatings, J. Electrochem. Soc, 157 (2010) C282-C287.

[51] W. Pinc, S. Maddela, W. Fahrenholtz, M. O’Keefe, Corrosion Protection of Cerium-based Conversion Coatings With Subsurface Crevices ECS Trans., 28 (2010) 187-201.

[52] S.-I. Pyun, S.-M. Moon, The inhibition mechanism of pitting corrosion of pure aluminum by nitrate and sulfate ions in neutral chloride solution, J. Solid State Electrochem., 3 (1999) 331-336.

[53] R. Arrabal, B. Mingo, A. Pardo, M. Mohedano, E. Matykina, I. Rodríguez, Pitting corrosion of rheocast A356 aluminium alloy in 3.5 wt.\% NaCl solution, Corros. Sci., 73 (2013) 342-355.

[54] F.H. Scholes, C. Soste, A.E. Hughes, S.G. Hardin, P.R. Curtis, The role of hydrogen peroxide in the deposition of cerium-based conversion coatings, Appl. Surf. Sci., 253 (2006) 1770-1780.

[55] B. Valdez, S. Kiyota, M. Stoytcheva, R. Zlatev, J.M. Bastidas, Cerium-based conversion coatings to improve the corrosion resistance of aluminium alloy 6061-T6, Corros. Sci., 87 (2014) 141-149.

[56] K. Nis,ancioğlu, Electrochemical Behaviorof Aluminum-Base Intermetallics Containing Iron, J. Electrochem. Soc., 137 (1990) 69-77.

[57] E. McCafferty, Introduction to Corrosion Science, Springer New York, 2010.

[58] D. Snihirova, S.V. Lamaka, M.F. Montemor, Smart composite coatings for corrosion protection of aluminium alloys in aerospace applications, in: M.F. Montemor (Ed.) Smart Composite Coatings and Membranes 2016.

[59] P. Burroughs, A.H. Anthony, F. Orchard, G. Thornton, Satellite structure in the X-ray photoelectron spectra of some binary and mixed oxides of lanthanum and cerium, J. Chem. Soc., Dalton Trans., (1976) 1686-1698.

[60] M. Romeo, K. Bak, J. El Fallah, F. Le Normand, L. Hilaire, XPS Study of the reduction of cerium dioxide, Surface and Interface Analysis, 20 (1993) 508-512. 
[61] M. Dabalà, L. Armelao, A. Buchberger, I. Calliari, Cerium-based conversion layers on aluminum alloys, Appl. Surf. Sci., 172 (2001) 312-322.

[62] S.S.A. Rehim, H.H. Hassan, M.A. Amin, Chronoamperometric studies of pitting corrosion of $\mathrm{Al}$ and (Al-Si) alloys by halide ions in neutral sulphate solutions, Corros. Sci., 46 (2004) 1921-1938.

[63] C.M. Dinnis, A.K. Dahle, J.A. Taylor, Three-dimensional analysis of eutectic grains in hypoeutectic Al-Si alloys, Mater. Sci. Eng., A, 392 (2005) 440-448.

[64] B. Mingo, R. Arrabal, A. Pardo, E. Matykina, P. Skeldon, 3D study of intermetallics and their effect on the corrosion morphology of rheocast aluminium alloy, Mater. Charact., 112 (2016) 122-128.

[65] M.A. Amin, Uniform and pitting corrosion events induced by $\mathrm{SCN}-$ anions on $\mathrm{Al}$ alloys surfaces and the effect of UV light, Electrochim. Acta, 56 (2011) 2518-2531.

\section{$\underline{\text { List of Figure Captions }}$}

Fig. 1. SEM-BS images of alloy (a) $2 R$ and (b) $4 R$.

Fig. 2. SEM-BS images of $2 \mathrm{R}$ alloy treated using the solution of (a) $0.01 \mathrm{~mol} / 1 \mathrm{Ce}\left(\mathrm{NO}_{3}\right)_{3}$, (b) $0.05 \mathrm{~mol} / 1 \mathrm{Ce}\left(\mathrm{NO}_{3}\right)_{3}$ and (c) $0.1 \mathrm{~mol} / \mathrm{l} \mathrm{Ce}\left(\mathrm{NO}_{3}\right)_{3}$ for 18 hours.

Fig. 3. SEM-BS images of $2 \mathrm{R}$ alloy treated using the solution of (a) $0.05 \mathrm{~mol} / \mathrm{l} \mathrm{Ce}\left(\mathrm{NO}_{3}\right)_{3}$ and $0.1 \mathrm{~mol} / \mathrm{l} \mathrm{NaCl}$ for 18 hours, (b) $0.05 \mathrm{~mol} / \mathrm{l} \mathrm{Ce}\left(\mathrm{NO}_{3}\right)_{3}$ and $0.02 \mathrm{~mol} / 1 \mathrm{H}_{2} \mathrm{O}_{2}$ for 1 hour and (c) $0.05 \mathrm{~mol} / \mathrm{l} \mathrm{Ce}\left(\mathrm{NO}_{3}\right)_{3}, 0.05 \mathrm{~mol} / 1 \mathrm{NaCl}$ and 0.02 $\mathrm{mol} / \mathrm{l} \mathrm{H}_{2} \mathrm{O}_{2}$ for 1 hour.

Fig. 4. SEM-BS image and EDXS analysis of $2 \mathrm{R}$ alloy treated using the solution of $0.05 \mathrm{~mol} / \mathrm{le}\left(\mathrm{NO}_{3}\right)_{3}$ and $0.1 \mathrm{~mol} / \mathrm{l}$ $\mathrm{NaCl}$ for 18 hours.

Fig. 5. SEM-BS images of $4 \mathrm{R}$ alloy treated using the solution of (a) $0.05 \mathrm{~mol} / \mathrm{l} \mathrm{Ce}\left(\mathrm{NO}_{3}\right)_{3}$ and $0.1 \mathrm{~mol} / \mathrm{l} \mathrm{NaCl}$ for 18 hours, (b) $0.05 \mathrm{~mol} / \mathrm{l} \mathrm{Ce}\left(\mathrm{NO}_{3}\right)_{3}$ and $0.02 \mathrm{~mol} / 1 \mathrm{H}_{2} \mathrm{O}_{2}$ for 1 hour (c) $0.05 \mathrm{~mol} / \mathrm{l} \mathrm{Ce}\left(\mathrm{NO}_{3}\right)_{3}, 0.05 \mathrm{~mol} / \mathrm{l} \mathrm{NaCl}$ and 0.02 $\mathrm{mol} / \mathrm{l} \mathrm{H}_{2} \mathrm{O}_{2}$ for 1 hour.

Fig. 6. (a) SEM-BS image and (b), (c), (d), (e) and (f) the elemental mapping of cross-sectional view of $2 \mathrm{R}$ alloy treated using the solution of $0.05 \mathrm{~mol} / \mathrm{l} \mathrm{Ce}\left(\mathrm{NO}_{3}\right)_{3}$ for 18 hours.

Fig. 7. (a) SEM-BS image and (b), (c), (d), (e) and (f) the elemental mapping of cross-sectional view of $2 \mathrm{R}$ alloy treated using the solution of $0.05 \mathrm{~mol} / \mathrm{l} \mathrm{Ce}\left(\mathrm{NO}_{3}\right)_{3}$ and $0.1 \mathrm{~mol} / 1 \mathrm{NaCl}$ for 18 hours.

Fig. 8. (a) SEM-BS image of underneath a cerium-based nuclei (the sample treated using the solution of $0.05 \mathrm{~mol} / \mathrm{l}$ $\mathrm{Ce}\left(\mathrm{NO}_{3}\right)_{3}$ and $0.1 \mathrm{~mol} / 1 \mathrm{NaCl}$ for 18 hours), (b), (c) and (d) EDXS results from different points in the SEM image.

Fig. 9. Formation mechanism of the cerium-based conversion coating.

Fig. 10. XPS analysis of $2 \mathrm{R}$ alloy treated using the solution of (a), (d), (g) $0.05 \mathrm{~mol} / \mathrm{l} \mathrm{Ce}\left(\mathrm{NO}_{3}\right)_{3}$ for 18 hours; (b), (e), (h) $0.05 \mathrm{~mol} / 1 \mathrm{Ce}\left(\mathrm{NO}_{3}\right)_{3}$ and $0.1 \mathrm{~mol} / 1 \mathrm{NaCl}$ for 18 hours; (c), (f), (i) $0.05 \mathrm{~mol} / 1 \mathrm{Ce}\left(\mathrm{NO}_{3}\right)_{3}$ and $0.02 \mathrm{~mol} / 1 \mathrm{H}_{2} \mathrm{O}_{2}$ for 1 hour.

Fig. 11. Bode plots of EIS spectra of treated samples of $2 \mathrm{R}$ alloy using the conversion solutions of (a), (d) $\mathrm{x} \mathrm{mol} / \mathrm{l}$ $\mathrm{Ce}\left(\mathrm{NO}_{3}\right)_{3}$ for 18 hours, (b), (e) $0.05 \mathrm{~mol} / 1 \mathrm{Ce}\left(\mathrm{NO}_{3}\right)_{3}$ and $\mathrm{x} \mathrm{mol} / 1 \mathrm{NaCl}$ for 18 hours, (c), (f) $0.05 \mathrm{~mol} / 1 \mathrm{Ce}\left(\mathrm{NO}_{3}\right)_{3}, 0.02$ $\mathrm{mol} / \mathrm{l} \mathrm{H}_{2} \mathrm{O}_{2}$ for 20 minutes and 1 hour. 
Fig. 12. Bode plots of EIS spectra of treated samples of $2 \mathrm{R}$ alloy using the conversion solutions of $0.05 \mathrm{~mol} / \mathrm{l}$ $\mathrm{Ce}\left(\mathrm{NO}_{3}\right)_{3}, 0.05 \mathrm{~mol} / 1 \mathrm{NaCl}$ and $0.02 \mathrm{~mol} / 1 \mathrm{H}_{2} \mathrm{O}_{2}$ for 20 minutes and 1 hour after (a) 6 and (b) 24 hours of EIS test.

Fig. 13. Bode plots of EIS spectra of treated samples of $4 \mathrm{R}$ alloy using the conversion solutions of (a), (d) $x$ mol/l $\mathrm{Ce}\left(\mathrm{NO}_{3}\right)_{3}$, (b), (e) $0.05 \mathrm{~mol} / 1 \mathrm{Ce}\left(\mathrm{NO}_{3}\right)_{3}$ and $\mathrm{x} \mathrm{mol} / 1 \mathrm{NaCl}$ for 18 hours, (c), (f) $0.05 \mathrm{~mol} / \mathrm{l} \mathrm{Ce}\left(\mathrm{NO}_{3}\right)_{3}, 0.02(0.01) \mathrm{mol} / 1$ $\mathrm{H}_{2} \mathrm{O}_{2}$ for 20 minutes and 1 hour.

Fig. 14. Bode plots of EIS spectra of treated samples of $4 \mathrm{R}$ alloy using the conversion solutions of $0.05 \mathrm{~mol} / \mathrm{l}$ $\mathrm{Ce}\left(\mathrm{NO}_{3}\right)_{3}, 0.05(0.01) \mathrm{mol} / \mathrm{l} \mathrm{NaCl}$ and $0.02 \mathrm{~mol} / 1 \mathrm{H}_{2} \mathrm{O}_{2}$ for 20 minutes and 1 hour after (a) 6 and (b) 24 hours of EIS test.

Fig. 15. SEM-BS image of the corroded surface of treated $4 \mathrm{R}$ alloy using the conversion solution of $0.05 \mathrm{~mol} / \mathrm{l}$ $\mathrm{Ce}\left(\mathrm{NO}_{3}\right)_{3}, 0.01 \mathrm{~mol} / 1 \mathrm{NaCl}$ and $0.02 \mathrm{~mol} / 1 \mathrm{H}_{2} \mathrm{O}_{2}$ for 1 hour.

Fig. 16. Potentiodynamic polarization curves of CeCCs on $2 \mathrm{R}$ and $4 \mathrm{R}$ alloys in $0.05 \mathrm{~mol} / \mathrm{l} \mathrm{NaCl}$ solution.

\section{$\underline{\text { List of Table Captions }}$}

Table. 1. Details of conversion process parameters

Table. 2. Summary of results derived from XPS spectra of the cerium-based conversion layer 
Table. 1. Details of conversion process parameters

\begin{tabular}{lllll}
\hline Substrate & $\mathrm{Ce}\left(\mathrm{NO}_{3}\right)_{3} \cdot 6 \mathrm{H}_{2} \mathrm{O}(\mathrm{mol} / \mathrm{l})$ & $\mathrm{NaCl}(\mathrm{mol} / \mathrm{l})$ & $\mathrm{H}_{2} \mathrm{O}_{2}(\mathrm{~mol} / \mathrm{l})$ & Immersion time $(\mathrm{h})$ \\
\hline Alloy 2R & $0.01,0.05,0.1$ & $0.01,0.05,0.1$ & 0 & 18 \\
\cline { 2 - 5 } & 0.05 & 0.05 & 0.02 & $0.3(20 \mathrm{~m}), 1$, \\
\hline Alloy 4R & $0.01,0.05,0.1$ & & 0 & 18 \\
\cline { 2 - 5 } & 0.05 & $0.01,0.05,0.1$ & $0.3(20 \mathrm{~m}), 1$ \\
\hline
\end{tabular}

Table. 2. Summary of results derived from XPS spectra of the cerium-based conversion layer

\begin{tabular}{|c|c|c|c|c|c|c|}
\hline $\begin{array}{l}\text { Conversion } \\
\text { solution }\end{array}$ & & $\mathrm{Ce}_{2} \mathrm{O}_{3}$ & $\mathrm{CeO}_{2}$ & $\mathrm{Ce}_{2} \mathrm{O}_{3}$ & $\mathrm{CeO}_{2}$ & $\mathrm{CeO}_{2}$ \\
\hline $0.05 \mathrm{~mol} / \mathrm{l}$ & Ce3d5/2 & $\mathrm{V}_{0}$ & $\mathrm{~V}$ & $V^{\prime}$ & V" & V"” \\
\hline \multirow[t]{3}{*}{$\mathrm{Ce}\left(\mathrm{NO}_{3}\right)_{3}$} & $\mathrm{BE}$ & 880.6 & 882.0 & 885.3 & 888.1 & 897.4 \\
\hline & $\mathrm{Ce} 3 \mathrm{~d} 3 / 2$ & $\mathrm{U}_{0}$ & $\mathrm{U}$ & U' & U" & U"' \\
\hline & $\mathrm{BE}$ & 899.0 & 900.7 & 903.8 & 906.8 & 916.1 \\
\hline \multirow{4}{*}{$\begin{array}{l}0.05 \mathrm{~mol} / \mathrm{l} \\
\mathrm{Ce}\left(\mathrm{NO}_{3}\right)_{3} \text { and } 0.1 \\
\mathrm{~mol} / 1 \mathrm{NaCl}\end{array}$} & $\mathrm{Ce} 3 \mathrm{~d} 5 / 2$ & $\mathrm{~V}_{0}$ & $\mathrm{~V}$ & $V^{\prime}$ & V" & V"” \\
\hline & $\mathrm{BE}$ & 880.2 & 882.1 & 885.3 & 888.0 & 897.7 \\
\hline & $\mathrm{Ce} 3 \mathrm{~d} 3 / 2$ & $\mathrm{U}_{0}$ & U & $\mathrm{U}^{\prime}$ & U" & U"” \\
\hline & $\mathrm{BE}$ & 898.0 & 900.9 & 903.9 & 906.8 & 916.2 \\
\hline \multirow{4}{*}{$\begin{array}{l}0.05 \mathrm{~mol} / \mathrm{l} \\
\mathrm{Ce}\left(\mathrm{NO}_{3}\right)_{3} \text { and } 0.02 \\
\mathrm{~mol} / 1 \mathrm{H}_{2} \mathrm{O}_{2}\end{array}$} & $\mathrm{Ce} 3 \mathrm{~d} 5 / 2$ & $\mathrm{~V}_{0}$ & V & $\mathrm{V}^{\prime}$ & V" & V"" \\
\hline & $\mathrm{BE}$ & 879.7 & 882.6 & 886.1 & 888.9 & 895.9 \\
\hline & $\mathrm{Ce} 3 \mathrm{~d} 3 / 2$ & $\mathrm{U}_{0}$ & $\mathrm{U}$ & $\mathrm{U}^{\prime}$ & U" & U"' \\
\hline & $\mathrm{BE}$ & 898.2 & 901.1 & 904.4 & 907.3 & 916.5 \\
\hline
\end{tabular}



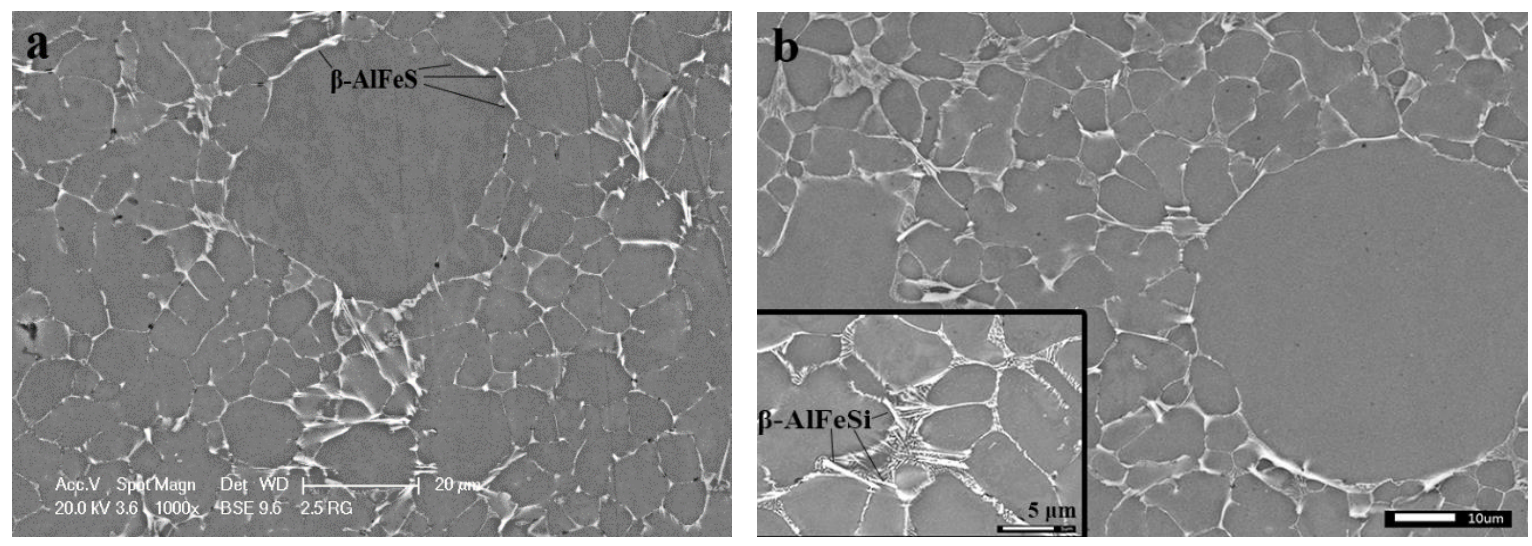

Fig. 1. SEM-BS images of alloy (a) $2 R$ and (b) $4 R$.
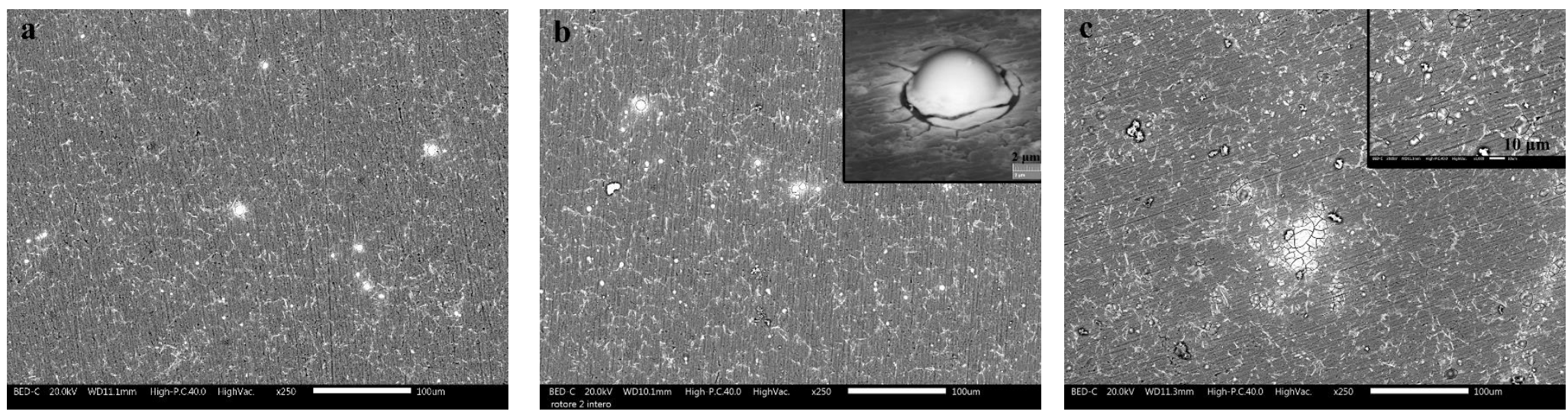

Fig. 2. SEM-BS images of $2 \mathrm{R}$ alloy treated using the solution of (a) $0.01 \mathrm{~mol} / 1 \mathrm{Ce}\left(\mathrm{NO}_{3}\right)_{3}$, (b) $0.05 \mathrm{~mol} / \mathrm{l} \mathrm{Ce}\left(\mathrm{NO}_{3}\right)_{3}$ and (c) $0.1 \mathrm{~mol} / 1 \mathrm{Ce}\left(\mathrm{NO}_{3}\right)_{3}$ for 18 hours. 

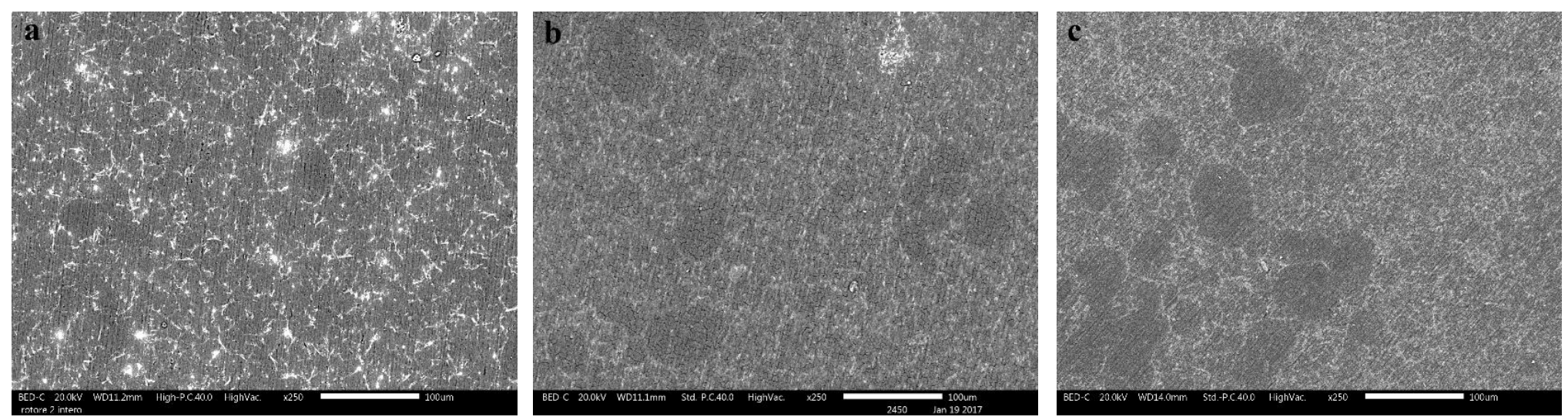

Fig. 3. SEM-BS images of $2 \mathrm{R}$ alloy treated using the solution of (a) $0.05 \mathrm{~mol} / \mathrm{l} \mathrm{Ce}\left(\mathrm{NO}_{3}\right)_{3}$ and $0.1 \mathrm{~mol} / 1 \mathrm{NaCl}$ for 18 hours, (b) $0.05 \mathrm{~mol} / 1 \mathrm{Ce}\left(\mathrm{NO}_{3}\right)_{3}$ and $0.02 \mathrm{~mol} / 1 \mathrm{H}_{2} \mathrm{O}_{2}$ for 1 hour and (c) $0.05 \mathrm{~mol} / \mathrm{l} \mathrm{Ce}\left(\mathrm{NO}_{3}\right)_{3}, 0.05 \mathrm{~mol} / 1 \mathrm{NaCl}$ and $0.02 \mathrm{~mol} / 1 \mathrm{H}_{2} \mathrm{O}_{2}$ for 1 hour.

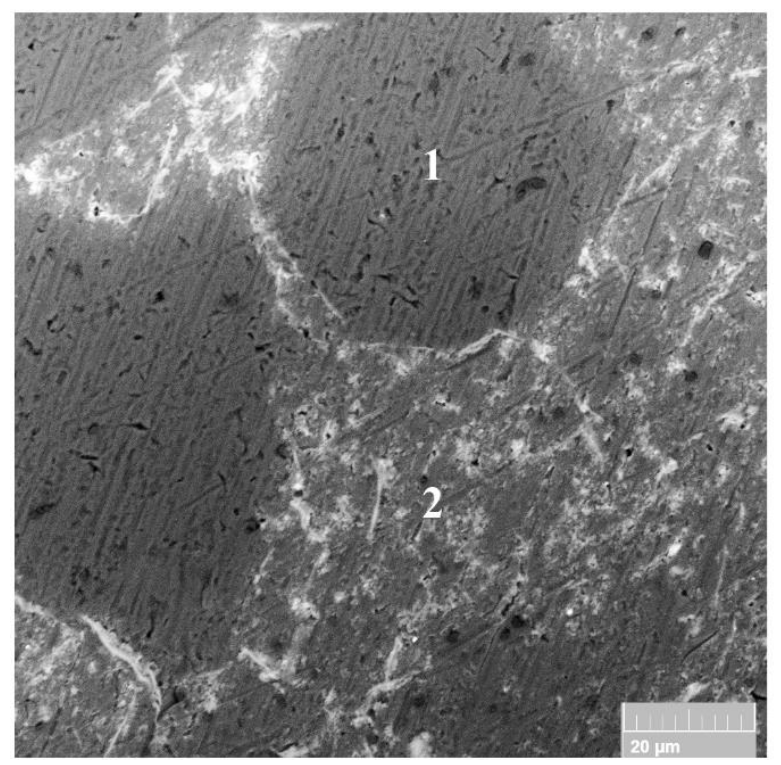

\begin{tabular}{cc}
\hline & \\
Element & Weight $\%$ \\
OK & 1.6 \\
\hline AlK & 96.1 \\
\hline SiK & 1.9 \\
\hline CeL & 0.2 \\
\hline FeK & 0.2 \\
\hline $\mathbf{2}$ & \\
\hline Element & Weight $\%$ \\
\hline OK & 6.3 \\
\hline AlK & 80.3 \\
\hline SiK & 6.2 \\
\hline Cel & 5.6 \\
\hline FeK & 1.3 \\
\hline
\end{tabular}

Fig. 4. SEM-BS image and EDXS analysis of $2 \mathrm{R}$ alloy treated using the solution of $0.05 \mathrm{~mol} / \mathrm{l} \mathrm{Ce}\left(\mathrm{NO}_{3}\right)_{3}$ and 0.1 $\mathrm{mol} / \mathrm{l} \mathrm{NaCl}$ for 18 hours. 

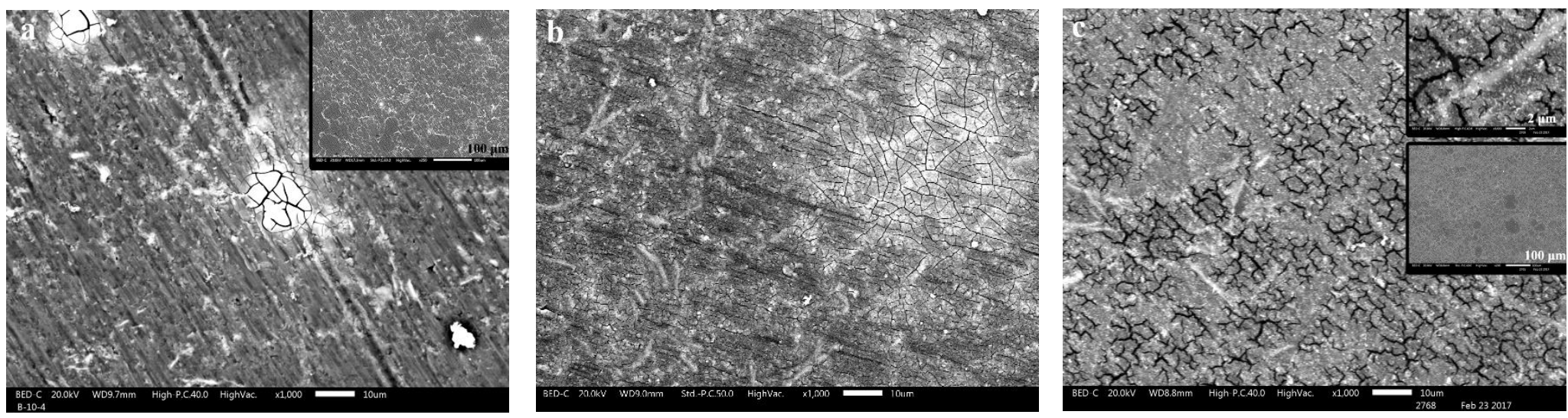

Fig. 5. SEM-BS images of $4 \mathrm{R}$ alloy treated using the solution of (a) $0.05 \mathrm{~mol} / \mathrm{l} \mathrm{Ce}\left(\mathrm{NO}_{3}\right)_{3}$ and $0.1 \mathrm{~mol} / 1 \mathrm{NaCl}$ for 18 hours, (b) $0.05 \mathrm{~mol} / \mathrm{l} \mathrm{Ce}\left(\mathrm{NO}_{3}\right)_{3}$ and $0.02 \mathrm{~mol} / 1 \mathrm{H}_{2} \mathrm{O}_{2}$ for 1 hour (c) $0.05 \mathrm{~mol} / \mathrm{l} \mathrm{Ce}\left(\mathrm{NO}_{3}\right)_{3}, 0.05 \mathrm{~mol} / 1 \mathrm{NaCl}$ and 0.02 $\mathrm{mol} / \mathrm{l} \mathrm{H}_{2} \mathrm{O}_{2}$ for 1 hour.
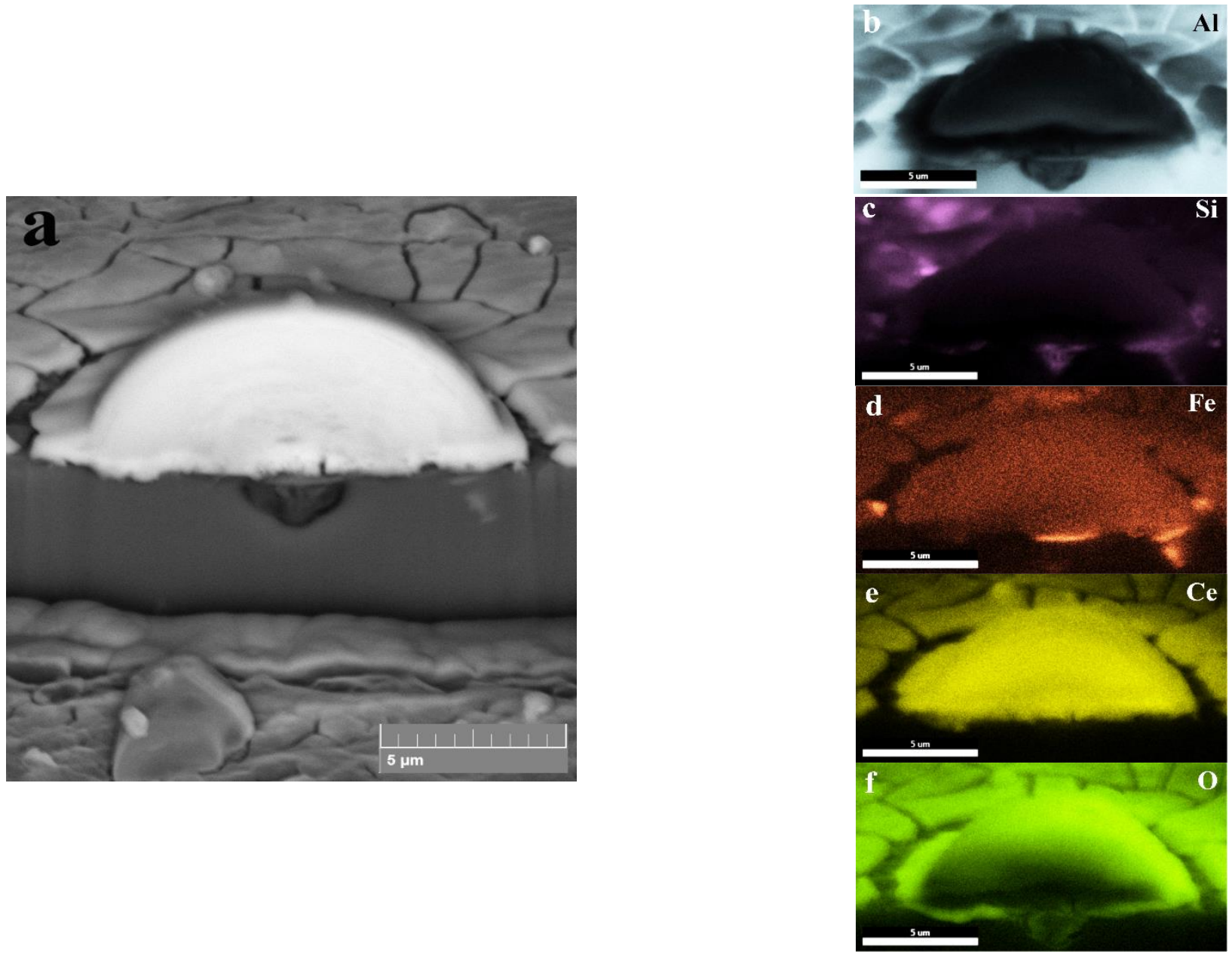

Fig. 6. (a) SEM-BS image and (b), (c), (d), (e) and (f) the elemental mapping of cross-sectional view of $2 \mathrm{R}$ alloy treated using the solution of $0.05 \mathrm{~mol} / \mathrm{l} \mathrm{Ce}\left(\mathrm{NO}_{3}\right)_{3}$ for 18 hours. 


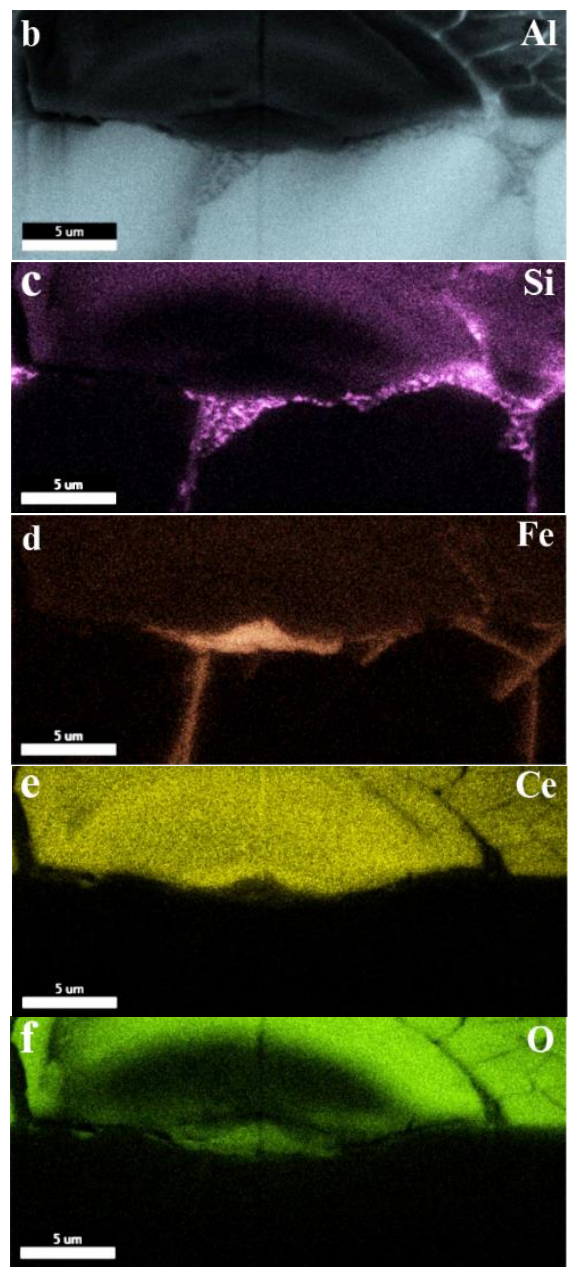

Fig. 7. (a) SEM-BS image and (b), (c), (d), (e) and (f) the elemental mapping of cross-sectional view of $2 \mathrm{R}$ alloy treated using the solution of $0.05 \mathrm{~mol} / \mathrm{l} \mathrm{Ce}\left(\mathrm{NO}_{3}\right)_{3}$ and $0.1 \mathrm{~mol} / 1 \mathrm{NaCl}$ for 18 hours. 

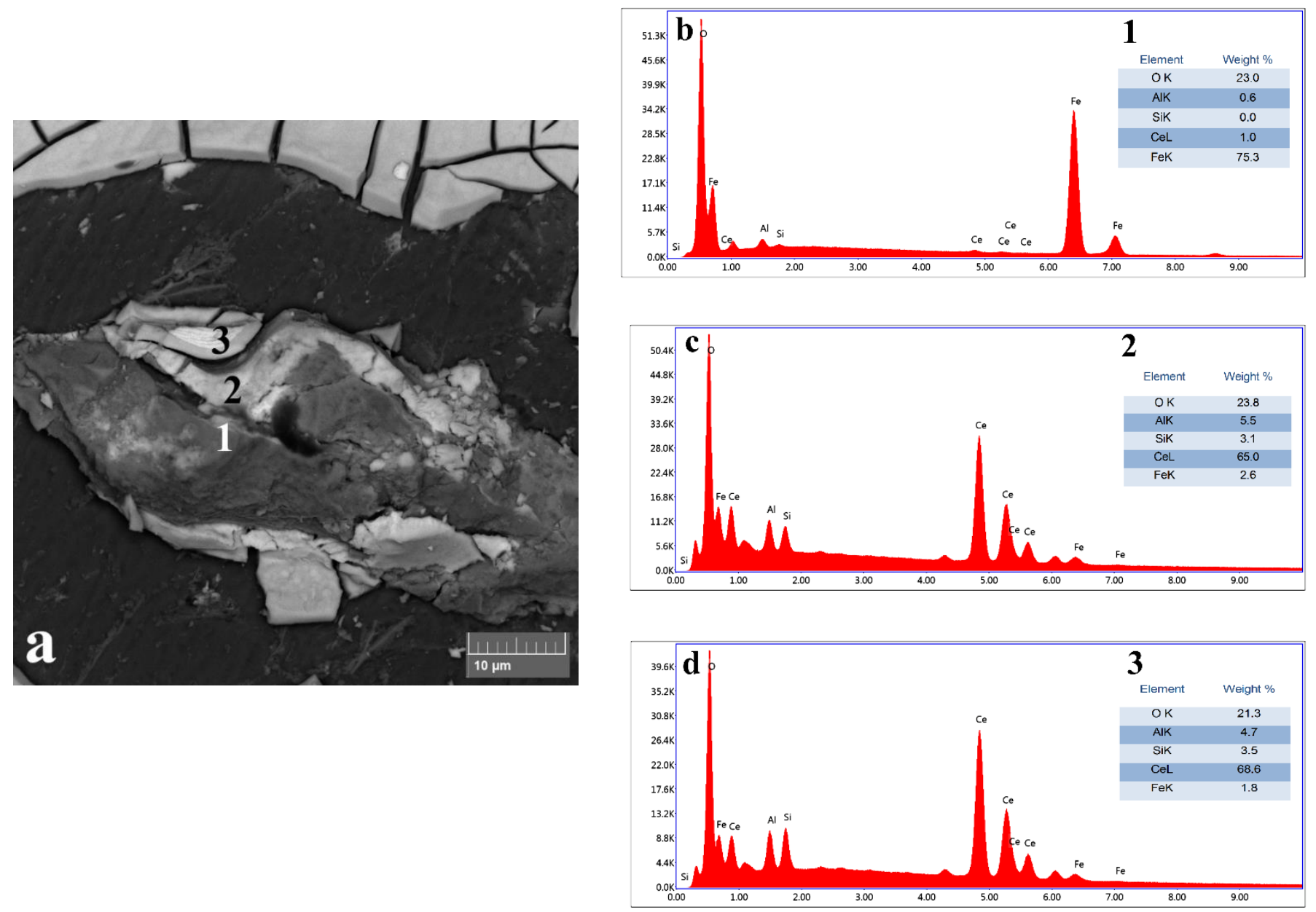

Fig. 8. (a) SEM-BS image of underneath a cerium-based nuclei (the sample treated using the solution of 0.05 $\mathrm{mol} / \mathrm{l} \mathrm{Ce}\left(\mathrm{NO}_{3}\right)_{3}$ and $0.1 \mathrm{~mol} / \mathrm{l} \mathrm{NaCl}$ for 18 hours), (b), (c) and (d) EDXS results from different points in the SEM image. 
I
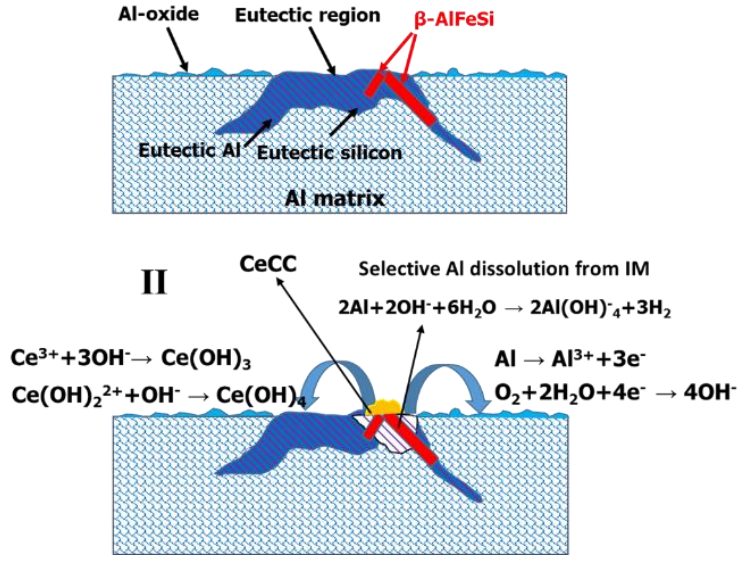
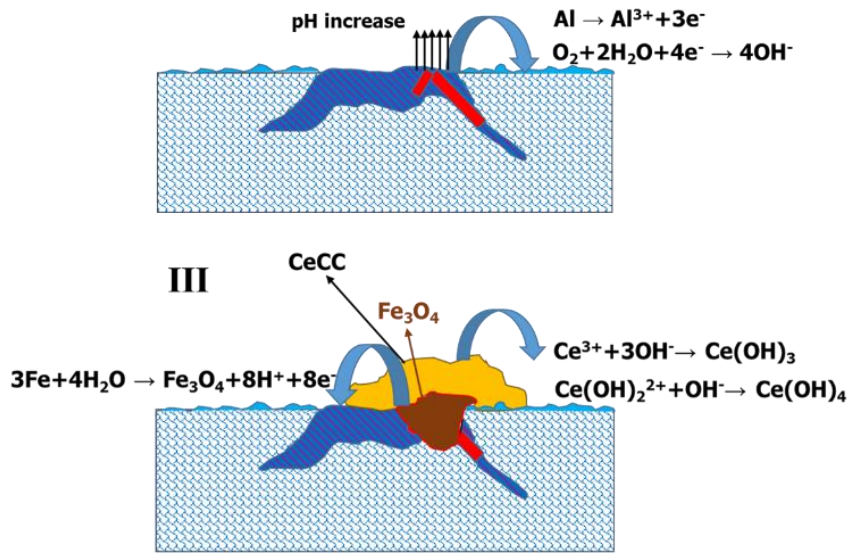

Fig. 9. Formation mechanism of the cerium-based conversion coating. 


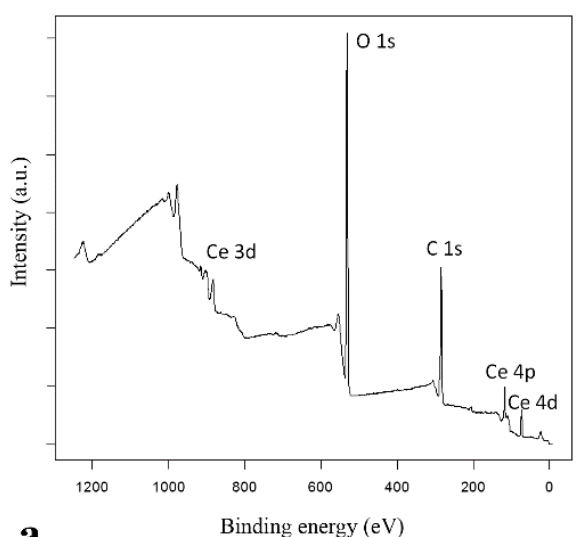

$\mathbf{a}$
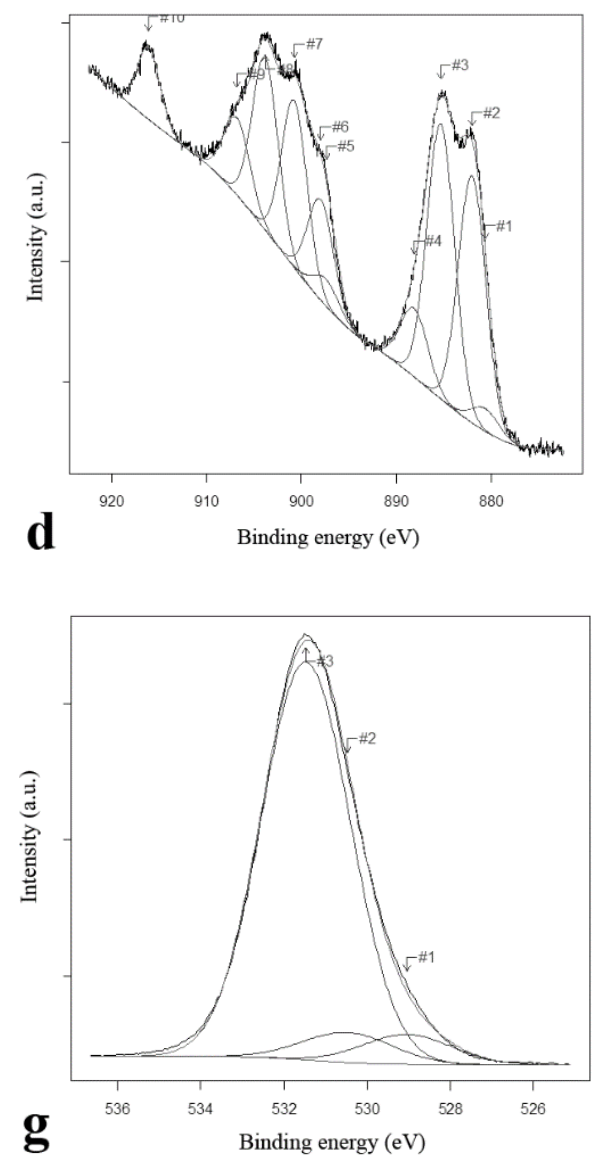
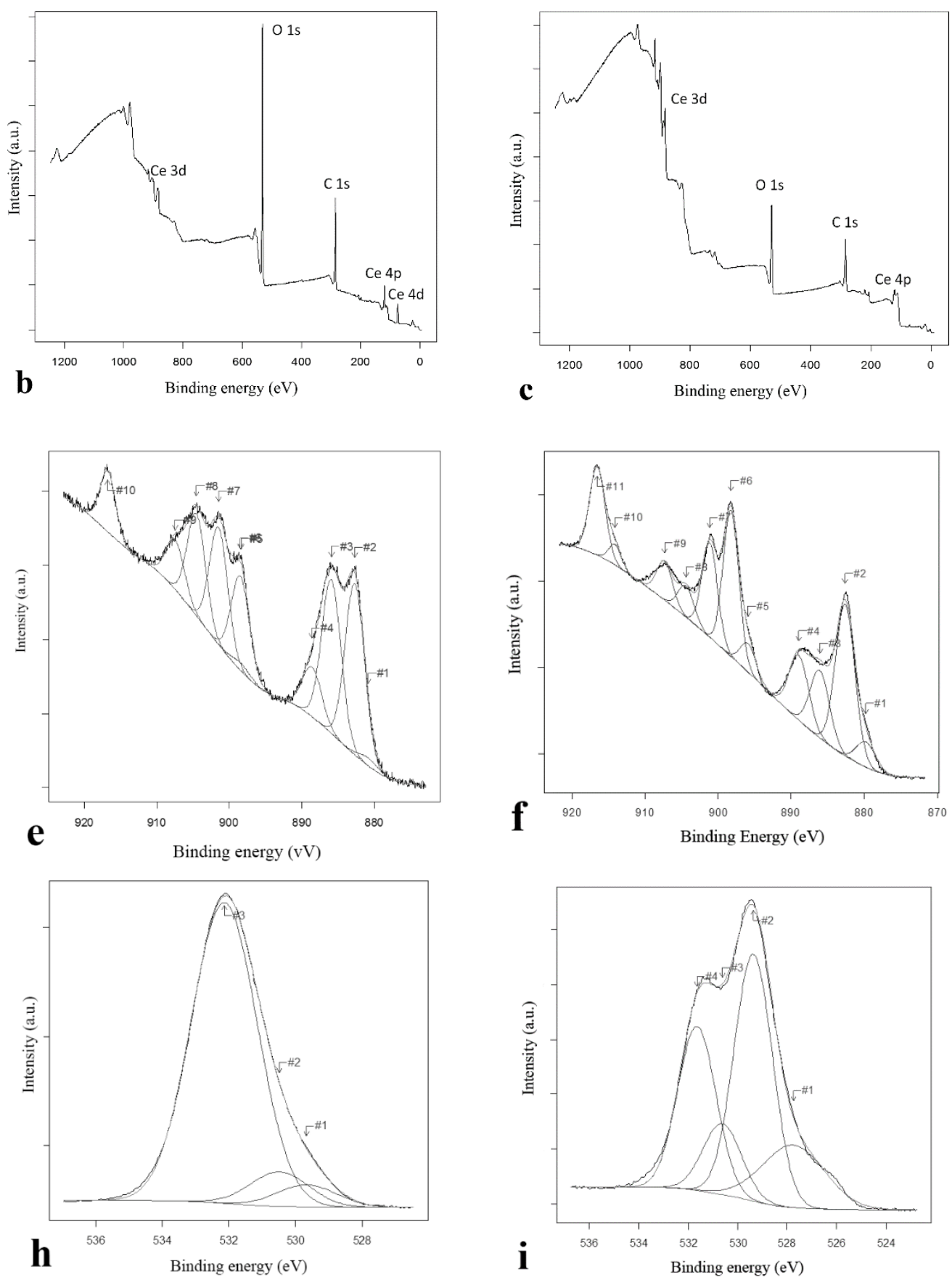

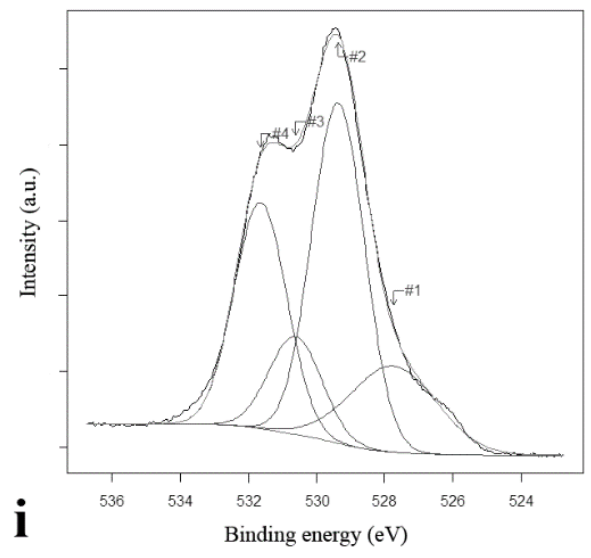

Fig. 10. XPS analysis of $2 \mathrm{R}$ alloy treated using the solution of (a), (d), (g) $0.05 \mathrm{~mol} / \mathrm{l} \mathrm{Ce}\left(\mathrm{NO}_{3}\right)_{3}$ for 18 hours; (b), (e), (h) $0.05 \mathrm{~mol} / 1 \mathrm{Ce}\left(\mathrm{NO}_{3}\right)_{3}$ and $0.1 \mathrm{~mol} / 1 \mathrm{NaCl}$ for 18 hours; (c), (f), (i) $0.05 \mathrm{~mol} / \mathrm{l} \mathrm{Ce}\left(\mathrm{NO}_{3}\right)_{3}$ and $0.02 \mathrm{~mol} / 1 \mathrm{H}_{2} \mathrm{O}_{2}$ for 1 hour. 

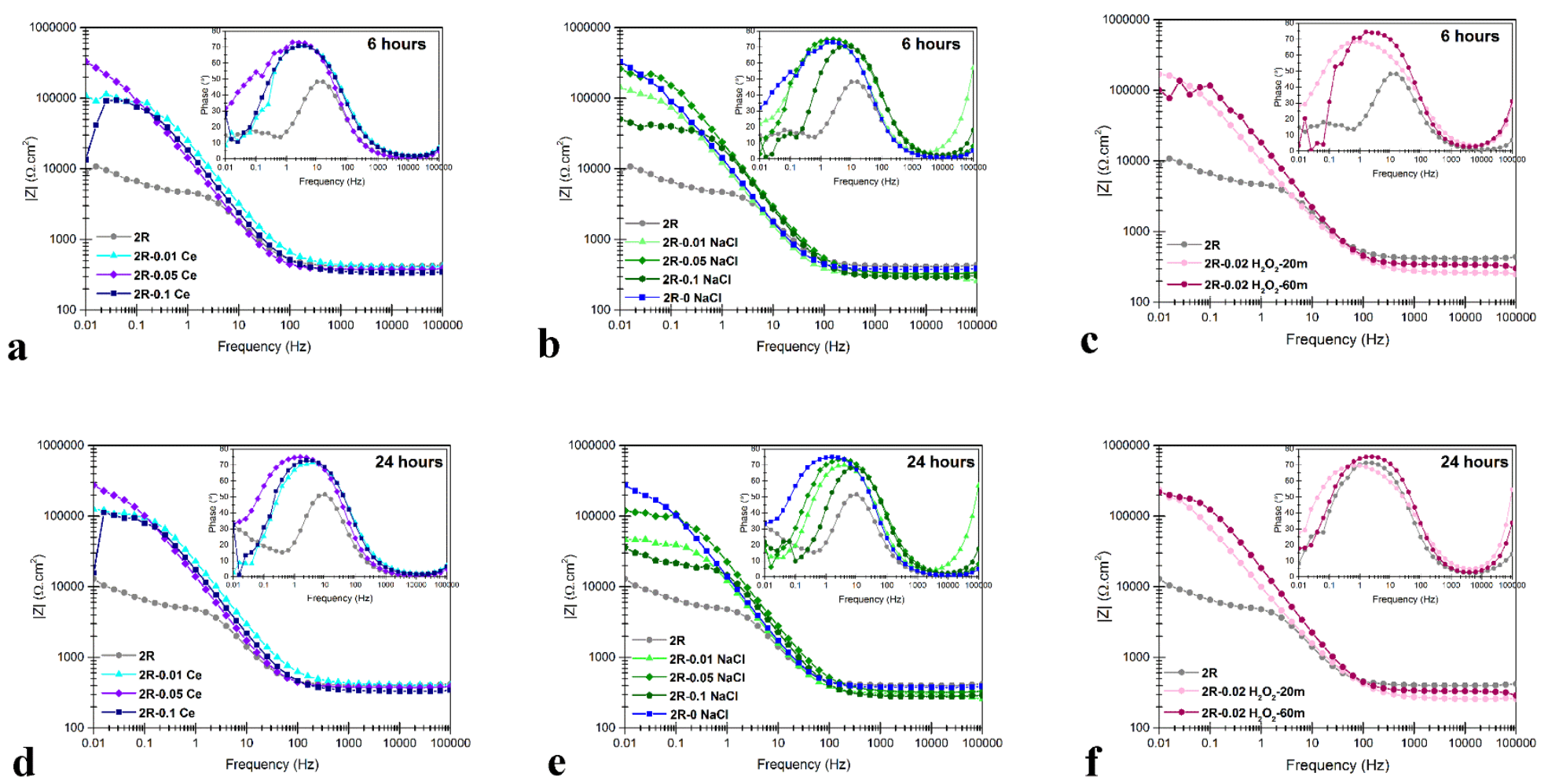

Fig. 11. Bode plots of EIS spectra of treated samples of $2 R$ alloy using the conversion solutions of (a), (d) $x$ mol/l $\mathrm{Ce}\left(\mathrm{NO}_{3}\right)_{3}$ for 18 hours, (b), (e) $0.05 \mathrm{~mol} / \mathrm{l} \mathrm{Ce}\left(\mathrm{NO}_{3}\right)_{3}$ and $\mathrm{x} \mathrm{mol} / 1 \mathrm{NaCl}$ for 18 hours, (c), (f) $0.05 \mathrm{~mol} / \mathrm{l} \mathrm{Ce}\left(\mathrm{NO}_{3}\right)_{3}$, $0.02 \mathrm{~mol} / 1 \mathrm{H}_{2} \mathrm{O}_{2}$ for 20 minutes and 1 hour.
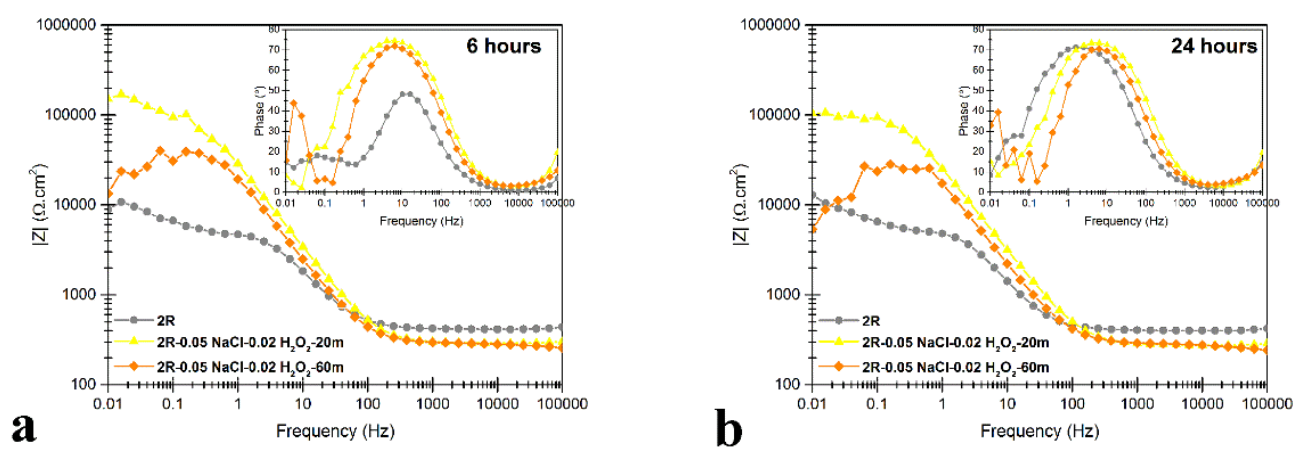

Fig. 12. Bode plots of EIS spectra of treated samples of $2 \mathrm{R}$ alloy using the conversion solutions of $0.05 \mathrm{~mol} / \mathrm{l}$ $\mathrm{Ce}\left(\mathrm{NO}_{3}\right)_{3}, 0.05 \mathrm{~mol} / \mathrm{l} \mathrm{NaCl}$ and $0.02 \mathrm{~mol} / 1 \mathrm{H}_{2} \mathrm{O}_{2}$ for 20 minutes and 1 hour after (a) 6 and (b) 24 hours of EIS test. 

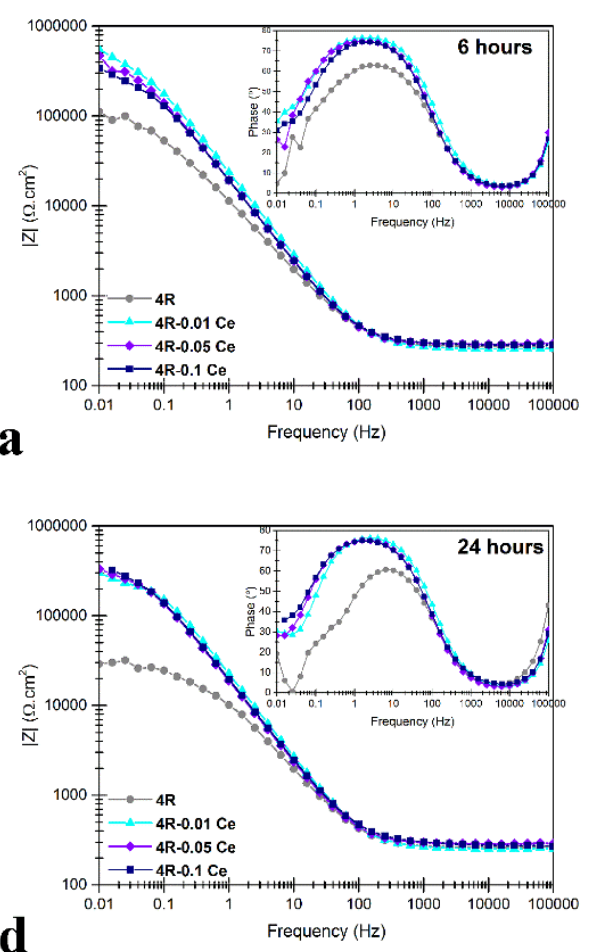
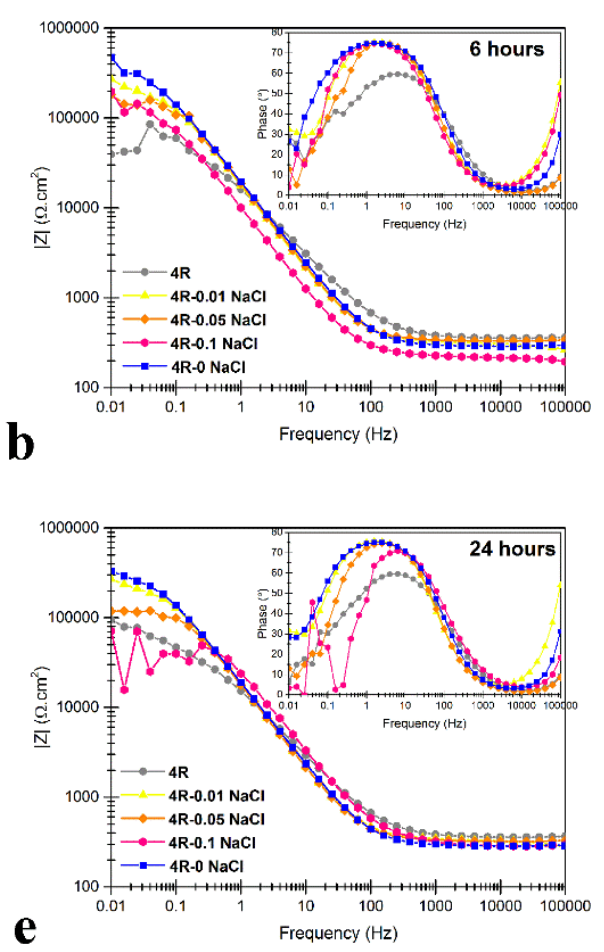
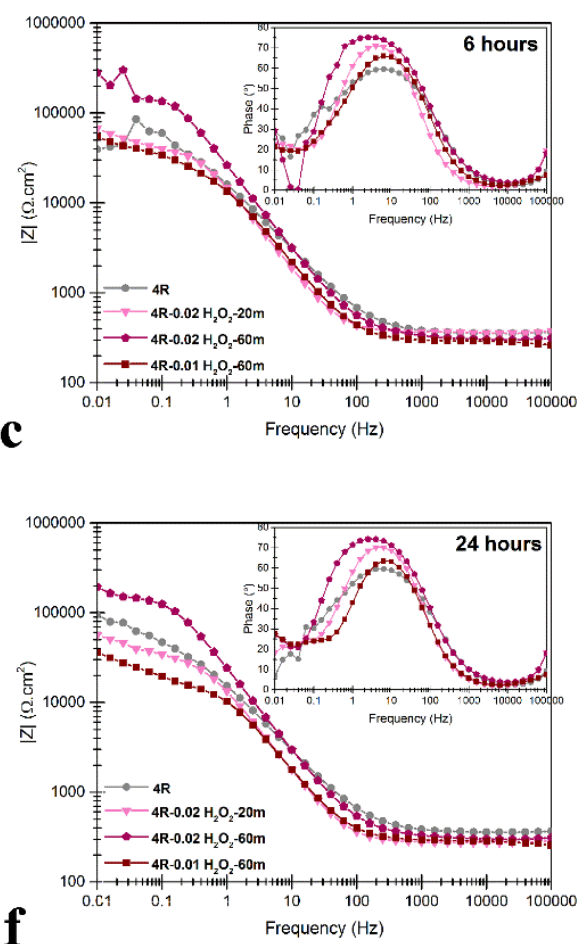

Fig. 13. Bode plots of EIS spectra of treated samples of $4 R$ alloy using the conversion solutions of (a), (d) $x \mathrm{~mol} / 1$ $\mathrm{Ce}\left(\mathrm{NO}_{3}\right)_{3}$, (b), (e) $0.05 \mathrm{~mol} / 1 \mathrm{Ce}\left(\mathrm{NO}_{3}\right)_{3}$ and $\mathrm{x} \mathrm{mol} / 1 \mathrm{NaCl}$ for 18 hours, (c), (f) $0.05 \mathrm{~mol} / \mathrm{l} \mathrm{Ce}\left(\mathrm{NO}_{3}\right)_{3}, 0.02(0.01) \mathrm{mol} / \mathrm{l}$ $\mathrm{H}_{2} \mathrm{O}_{2}$ for 20 minutes and 1 hour.
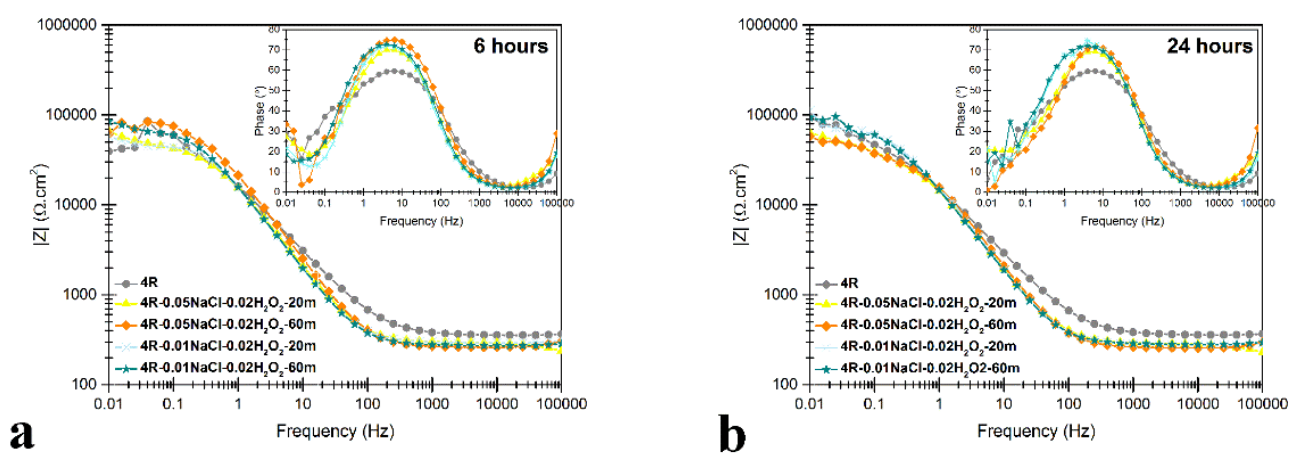

Fig. 14. Bode plots of EIS spectra of treated samples of $4 \mathrm{R}$ alloy using the conversion solutions of $0.05 \mathrm{~mol} / \mathrm{l}$ $\mathrm{Ce}\left(\mathrm{NO}_{3}\right)_{3}, 0.05(0.01) \mathrm{mol} / 1 \mathrm{NaCl}$ and $0.02 \mathrm{~mol} / 1 \mathrm{H}_{2} \mathrm{O}_{2}$ for 20 minutes and 1 hour after (a) 6 and (b) 24 hours of EIS test. 


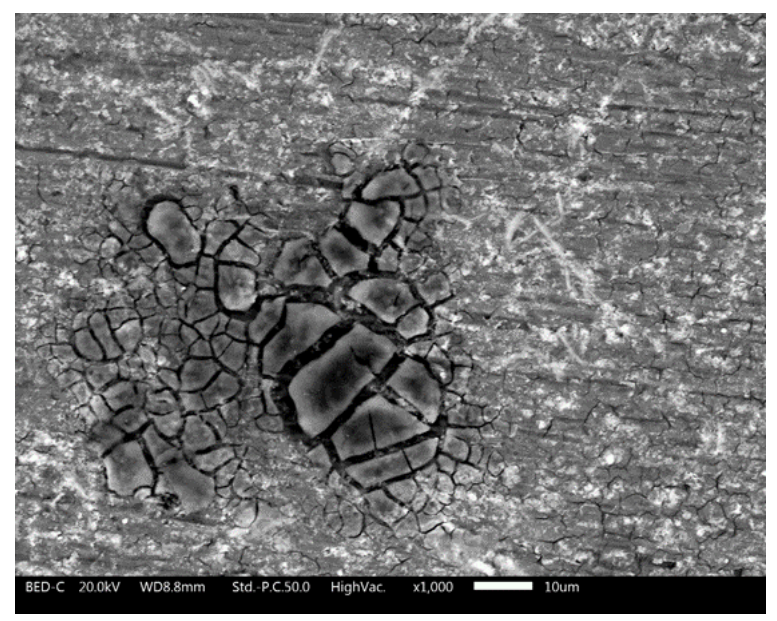

Fig. 15. SEM-BS image of the corroded surface of treated $4 \mathrm{R}$ alloy using the conversion solution of $0.05 \mathrm{~mol} / \mathrm{l}$ $\mathrm{Ce}\left(\mathrm{NO}_{3}\right)_{3}, 0.01 \mathrm{~mol} / \mathrm{l} \mathrm{NaCl}$ and $0.02 \mathrm{~mol} / 1 \mathrm{H}_{2} \mathrm{O}_{2}$ for 1 hour.

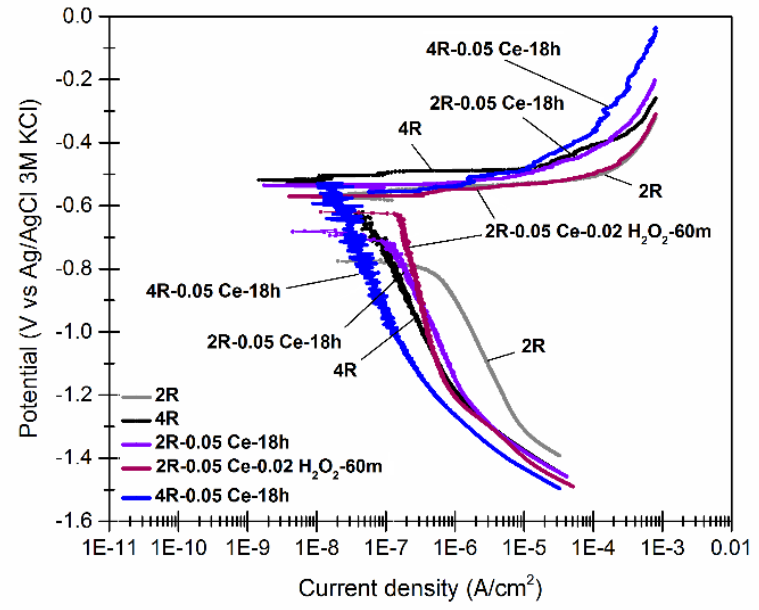

Fig. 16. Potentiodynamic polarization curves of CeCCs on $2 \mathrm{R}$ and $4 \mathrm{R}$ alloys in $0.05 \mathrm{~mol} / \mathrm{l} \mathrm{NaCl}$ solution. 

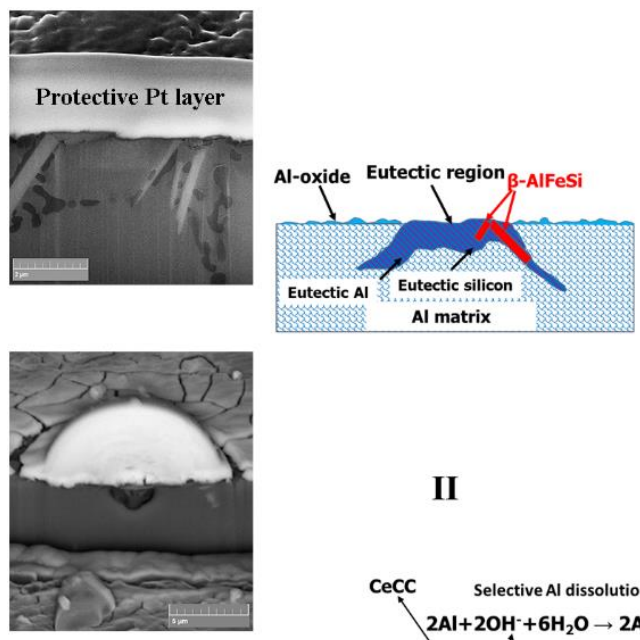

$\mathrm{Ce}^{3+}+3 \mathrm{OH}^{-} \rightarrow \mathrm{Ce}(\mathrm{OH})_{3}$
$\mathrm{Ce}(\mathrm{OH})_{2}{ }^{2+}+\mathrm{OH}^{-} \rightarrow \mathrm{Ce}(\mathrm{OH})_{4}$$\quad \begin{aligned} & \mathrm{Al} \rightarrow \mathrm{Al}^{3+}+3 \mathrm{e}^{-} \\ & \mathrm{O}_{2}+2 \mathrm{H}_{2} \mathrm{O}+4 \mathrm{e}^{-} \rightarrow 4 \mathrm{H}^{-}\end{aligned}$

CecC Selective Al dissolution from IM
II $2 \mathrm{Al}+2 \mathrm{OH}^{-}+6 \mathrm{H}_{2} \mathrm{O} \rightarrow 2 \mathrm{Al}(\mathrm{OH})^{-}{ }_{4}+3 \mathrm{H}_{2}$

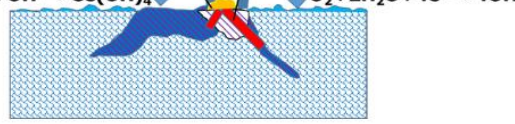

I

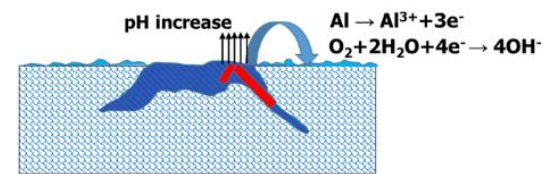

III

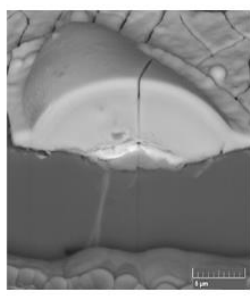

CeçC

$\mathrm{Fe}_{3} \mathrm{O}_{4} \bigcirc \mathrm{Ce}^{3+}+3 \mathrm{OH}^{-} \rightarrow \mathrm{Ce}(\mathrm{OH})_{3}$

$3 \mathrm{Fe}+4 \mathrm{H}_{2} \mathrm{O} \rightarrow \mathrm{Fe}_{3} \mathrm{O}_{4}+8 \mathrm{H}^{+}+8 \mathrm{e}^{-} \quad \begin{aligned} & \mathrm{Ce}(\mathrm{OH})_{2}{ }^{2+}+\mathrm{OH}^{-} \rightarrow \mathrm{Ce}(\mathrm{OH})_{4} \\ & .\end{aligned}$ 